\title{
Regulation of lipid peroxidation and ferroptosis in diverse species
}

\author{
Marcus Conrad, ${ }^{1}$ Valerian E. Kagan, ${ }^{2,3,4,5,6}$ Hülya Bayir, ${ }^{2,7}$ Gabriela C. Pagnussat, ${ }^{8}$ Brian Head, ${ }^{9,10}$ \\ Maret G. Traber, ${ }^{9,11}$ and Brent R. Stockwell ${ }^{12,13}$ \\ ${ }^{1}$ Institute of Developmental Genetics, Helmholtz Zentrum München, Deutsches Forschungszentrum für Gesundheit und Umwelt \\ $(\mathrm{GmbH}), 85764$ Neuherberg, Germany; ${ }^{2}$ Center for Free Radical and Antioxidant Health, University of Pittsburgh, Pittsburgh, \\ Pennsylvania 15213, USA; ${ }^{3}$ Department of Environmental Health, University of Pittsburgh, Pittsburgh, Pennsylvania 15213, USA; \\ ${ }^{4}$ Department of Chemistry, University of Pittsburgh, Pittsburgh, Pennsylvania 15213, USA; ${ }^{5}$ Department of Pharmacology and \\ Chemical Biology, University of Pittsburgh, Pittsburgh, Pennsylvania 15213, USA; ${ }^{6}$ Laboratory of Navigational Lipidomics of Cell \\ Death and Regeneration, I.M. Sechenov First Moscow State Medical University, Moscow 119992, Russia; ${ }^{7}$ Department of Critical \\ Care Medicine, University of Pittsburgh, Pittsburgh, Pennsylvania 15213, USA; ${ }^{8}$ Instituto de Investigaciones Biológicas, Consejo \\ Nacional de Investigaciones Científicas y Técnicas (CONICET), Universidad Nacional de Mar del Plata, 7600 Mar del Plata, \\ Argentina; ${ }^{9}$ Linus Pauling Institute, Oregon State University, Corvallis, Oregon 97330; ${ }^{10}$ Molecular and Cell Biology Graduate \\ Program, Oregon State University, Corvallis, Oregon 97330, USA; ${ }^{11}$ College of Public Health and Human Sciences, Oregon State \\ University, Corvallis, Oregon 97330, USA; ${ }^{12}$ Department of Biological Sciences, Columbia University, New York, New York \\ 10027, USA; ${ }^{13}$ Department of Chemistry, Columbia University, New York, New York 10027, USA
}

Lipid peroxidation is the process by which oxygen combines with lipids to generate lipid hydroperoxides via intermediate formation of peroxyl radicals. Vitamin $E$ and coenzyme $Q_{10}$ react with peroxyl radicals to yield peroxides, and then these oxidized lipid species can be detoxified by glutathione and glutathione peroxidase 4 (GPX4) and other components of the cellular antioxidant defense network. Ferroptosis is a form of regulated nonapoptotic cell death involving overwhelming iron-dependent lipid peroxidation. Here, we review the functions and regulation of lipid peroxidation, ferroptosis, and the antioxidant network in diverse species, including humans, other mammals and vertebrates, plants, invertebrates, yeast, bacteria, and archaea. We also discuss the potential evolutionary roles of lipid peroxidation and ferroptosis.

Ferroptosis is an iron-dependent oxidative form of cell death associated with increased lipid peroxidation and insufficient capacity to eliminate lipid peroxides. Ferroptosis is distinct by numerous criteria from apoptosis, necroptosis, classic necrosis, and other reported forms of cell death (Galluzzi et al. 2018). Historically, cell death involving iron and lipid peroxidation has been observed in diverse species, including mammals, birds, and fish, but was not attributed to ferroptosis, given that the term and concept were first introduced in 2012 (Dixon et al. 2012). It is clear, however, that disrupted iron ho-

[Keywords: ferroptosis; lipid peroxidation; cell death; iron; ROS; vitamin E]

Corresponding author: bstockwell@columbia.edu

Article is online at http://www.genesdev.org/cgi/doi/10.1101/gad.314674. 118 . meostasis and unchecked lipid peroxidation, two key characteristics of ferroptosis, are associated with pathologies in numerous animal species during diverse life states. Here, we summarize evidence for ferroptosis-like cell death and the functions and regulation of lipid peroxidation in several species representative of the diversity of life on Earth.

Regulated cell death mechanisms other than apoptosis have emerged in recent years (Conrad et al. 2016). The term ferroptosis was introduced (Dixon et al. 2012) to describe cell death induced by the compound erastin, which causes glutathione depletion through system $\mathrm{X}_{\mathrm{c}}{ }^{-}$ inhibition and consequently glutathione peroxidase 4 (GPX4) inactivation (see Fig. 1; Yang et al. 2014). GPX4 functions to remove lipid peroxides generated in phospholipid membranes (Ursini et al. 1982). Numerous compounds have been identified (such as erastin, RASselective lethal [RSL3], ferroptosis inducer 56 [FINF56], and ferroptosis inducer endoperoxide $\left[\mathrm{FINO}_{2}\right]$ ) that cause loss of GPX4 activity and overwhelming lipid peroxidation, resulting ultimately in cell death (Dixon et al. 2012; Yang et al. 2014). Ferroptosis may contribute to degenerative pathologies and might be therapeutically beneficial in some cancers (Stockwell et al. 2017).

Lipids containing polyunsaturated fatty acids (PUFAs) with labile bis-allylic hydrogen atoms are most susceptible to lipid peroxidation and are necessary for the normal execution of ferroptosis (Yang et al. 2016a). While other lipids can undergo peroxidation under extreme

(C) 2018 Conrad et al. This article is distributed exclusively by Cold Spring Harbor Laboratory Press for the first six months after the full-issue publication date (see http://genesdev.cshlp.org/site/misc/terms.xhtml). After six months, it is available under a Creative Commons License (Attribution-NonCommercial 4.0 International), as described at http:// creativecommons.org/licenses/by-nc/4.0/. 


\begin{tabular}{|c|c|c|c|c|c|c|c|c|}
\hline $\begin{array}{c}\text { Gene/Metabolite/ } \\
\text { Process }\end{array}$ & Humans & Mice & Fish & Birds & Plants & Yeast & Bacteria & Archaea \\
\hline GPX4 & $\begin{array}{c}\text { Mutations associated } \\
\text { with Sedaghatian type } \\
\text { of spondylometaphyseal } \\
\text { dysplasia }\end{array}$ & $\begin{array}{c}\text { Essential in } \\
\text { development and for } \\
\text { adult survival }\end{array}$ & $\begin{array}{c}\text { Present in fish and frogs, } \\
\text { but connection to } \\
\text { ferroptosis not } \\
\text { established }\end{array}$ & $\begin{array}{c}\text { Other GPX enzymes } \\
\text { are present }\end{array}$ & $\begin{array}{c}\text { Present but } \\
\text { function in } \\
\text { ferroptosis not clear }\end{array}$ & $\begin{array}{c}\text { Present but } \\
\text { function in } \\
\text { ferroptosis not } \\
\text { clear }\end{array}$ & $\begin{array}{c}\text { Express factors } \\
\text { regulate } \\
\text { mammalian } \\
\text { GPX4 }\end{array}$ & Unknown \\
\hline SLC7A11 & $\begin{array}{l}\text { Upregulated in cell } \\
\text { culture, necessary in } \\
\text { some cell lines to } \\
\text { suppress ferroptosis } \\
\end{array}$ & $\begin{array}{l}\text { Deletion in mice has } \\
\text { only mild phenotype }\end{array}$ & $\begin{array}{c}\text { Present in fish and frogs, } \\
\text { but connection to } \\
\text { ferroptosis not } \\
\text { established }\end{array}$ & $\begin{array}{c}\text { Present in chickens, } \\
\text { connection to } \\
\text { ferroptosis not } \\
\text { established } \\
\end{array}$ & Unknown & Unknown & Unknown & Unknown \\
\hline Glutathione & $\begin{array}{l}\text { Key cofactor for GPX4 } \\
\text { to suppress lipid } \\
\text { peroxidation and } \\
\text { ferroptosis in cell culture }\end{array}$ & $\begin{array}{c}\text { Key cofactor for GPX4 } \\
\text { to suppress lipid } \\
\text { peroxidation and } \\
\text { ferroptosis in mice }\end{array}$ & $\begin{array}{c}\text { Key antioxidant; used for } \\
\text { detoxification reactions } \\
\text { (GST) }\end{array}$ & Key antioxidant & $\begin{array}{c}\text { Works with } \\
\text { ascorbate to } \\
\text { suppress ROS }\end{array}$ & $\begin{array}{c}\text { Key } \\
\text { antioxidant }\end{array}$ & Key antioxidant & $\begin{array}{c}\text { Key } \\
\text { antioxidant }\end{array}$ \\
\hline ACSL4 & $\begin{array}{c}\begin{array}{c}\text { Knockdown or knock out } \\
\text { suppresses ferroptosis } \\
\text { in cell culture }\end{array} \\
\end{array}$ & $\begin{array}{c}\text { Loss of function } \\
\text { suppresses ferroptosis } \\
\text { in cells }\end{array}$ & $\begin{array}{c}\text { Present in fish and frogs, } \\
\text { but connection to } \\
\text { ferroptosis not } \\
\text { established }\end{array}$ & $\begin{array}{c}\text { Present in fish and } \\
\text { frogs, but connection } \\
\text { to ferroptosis not } \\
\text { established }\end{array}$ & $\begin{array}{c}\text { Present but } \\
\text { function in } \\
\text { ferroptosis not clear }\end{array}$ & Unknown & Unknown & Unknown \\
\hline PUFAs & $\begin{array}{l}\text { Essential for survival, } \\
\text { and can be esterified } \\
\text { and oxidized to } \\
\text { ferroptotic signals }\end{array}$ & $\begin{array}{c}\text { Essential for survival, } \\
\text { but can be esterified } \\
\text { and oxidized to } \\
\text { ferroptotic signals }\end{array}$ & $\begin{array}{l}\text { Abundant in egg yolk, } \\
\text { essential for } \\
\text { neurodevelopment }\end{array}$ & $\begin{array}{c}\text { Abundant in egg } \\
\text { yolk, essential for } \\
\text { neurodevelopment }\end{array}$ & $\begin{array}{l}\text { Essential for } \\
\text { ferroptosis }\end{array}$ & $\begin{array}{c}\text { Can drive } \\
\text { ferroptosis in } \\
\text { CoQ-deficient } \\
\text { yeast }\end{array}$ & \begin{tabular}{|c|} 
Most do not use \\
PUFAs
\end{tabular} & $\begin{array}{l}\text { Most do not } \\
\text { use PUFAs }\end{array}$ \\
\hline Lipoxygenases & Drivers of ferroptosis & Drivers of ferroptosis & $\begin{array}{l}\text { Have diverse functions, } \\
\text { not linked to ferroptosis }\end{array}$ & $\begin{array}{c}\text { Have diverse } \\
\text { functions, not linked } \\
\text { to ferroptosis }\end{array}$ & $\begin{array}{l}\text { Involved in cell } \\
\text { death and } \\
\text { ferroptosis } \\
\end{array}$ & Unknown & Unknown & Unknown \\
\hline PEBP1 & $\begin{array}{c}\text { Pro-ferroptotic complex } \\
\text { with lipoxygenases }\end{array}$ & $\begin{array}{c}\text { Pro-ferroptotic } \\
\text { complex with } \\
\text { lipoxygenases }\end{array}$ & $\begin{array}{l}\text { Present but function in } \\
\text { ferroptosis not clear }\end{array}$ & $\begin{array}{c}\begin{array}{c}\text { Present but function } \\
\text { in ferroptosis not } \\
\text { clear }\end{array} \\
\end{array}$ & $\begin{array}{c}\text { Present but } \\
\text { function in } \\
\text { ferroptosis not clear }\end{array}$ & $\begin{array}{c}\text { Present but } \\
\text { function in } \\
\text { ferroptosis not } \\
\text { clear }\end{array}$ & $\begin{array}{c}\begin{array}{c}\text { Present but } \\
\text { function in } \\
\text { ferroptosis not } \\
\text { clear }\end{array} \\
\end{array}$ & $\begin{array}{l}\text { Present but } \\
\text { function in } \\
\text { ferroptosis } \\
\text { not clear } \\
\end{array}$ \\
\hline $\mathrm{SBP} 2 / \mathrm{Se}$ & $\begin{array}{c}\text { Mutations in SBP2 } \\
\text { associated with lipid } \\
\text { peroxidation }\end{array}$ & Essential for survival & $\begin{array}{c}\text { More than } 30 \\
\text { selenoproteins have } \\
\text { been described in } \\
\text { zebrafish }\end{array}$ & $\begin{array}{c}\text { Selenium is povided } \\
\text { to eggs by chicken } \\
\text { mothers; deficiency } \\
\text { causes exudative } \\
\text { diathesis in broiler } \\
\text { birds }\end{array}$ & \begin{tabular}{|c|} 
Present in \\
Chlamydomonas \\
reinhardtii; \\
presence/function \\
in other plant \\
systems unknown
\end{tabular} & $\begin{array}{c}\text { Diverse } \\
\text { functions }\end{array}$ & $\begin{array}{c}\text { Diverse } \\
\text { functions }\end{array}$ & $\begin{array}{l}\text { Diverse } \\
\text { functions }\end{array}$ \\
\hline Vitamin $\mathrm{E}$ & \begin{tabular}{|c|} 
Essential for survival; $\alpha-$ \\
tocopherol availabilty \\
determined by TTP \\
expression; Vit E \\
deficiency causes \\
progressive peripheral \\
neuropathy; increased \\
miscarriage \\
\end{tabular} & \begin{tabular}{|c|} 
Essential for \\
embryonic survival; $\alpha-$ \\
tocopherol availabilty \\
determined by TTP \\
expression; Vit E \\
deficiency causes \\
progressive peripheral \\
neuropathy \\
\end{tabular} & $\begin{array}{c}\alpha \text {-tocopherol availabilty } \\
\text { determined by TTP } \\
\text { expression }\end{array}$ & $\begin{array}{c}\text { Provided to eggs by } \\
\text { chicken mothers }\end{array}$ & $\begin{array}{c}\text { Produced by many } \\
\text { plants }\end{array}$ & Unknown & Unknown & Unknown \\
\hline Lipid peroxidation & $\begin{array}{c}\text { Detected in human cells } \\
\text { in culture and in patient } \\
\text { biopsies; urine/plasma } \\
\text { F2-isoprostanes, } \\
\text { oxidized lipids } \\
\end{array}$ & \begin{tabular}{|c|} 
Detected in mouse \\
cells in culture and in \\
mouse tissue sections
\end{tabular} & $\begin{array}{c}\text { Increased in brain, } \\
\text { embryos by vitamin E, } \\
\text { ascorbic acid, GSH } \\
\text { deficiencies, decreased } \\
\text { by vitamin E }\end{array}$ & Detected & Detected & $\begin{array}{c}\text { Detected } \\
\text { under specific } \\
\text { conditions }\end{array}$ & $\begin{array}{l}\text { Not typically } \\
\text { observed }\end{array}$ & $\begin{array}{c}\text { Not typically } \\
\text { observed }\end{array}$ \\
\hline
\end{tabular}

Figure 1. Comparison of ferroptosis pathway components in diverse species. Several key genes, metabolites, and processes relevant to ferroptosis and lipid peroxidation are shown as well as a summary of their role in each species shown.

conditions, such as in the presence of ionizing radiation or upon photobleaching of dyes, the generation of lipid peroxides in cells under normal circumstances is dependent on the availability of PUFA tails with their readily removable hydrogen atoms. Thus, the ability of cells to undergo ferroptosis ordinarily depends on the abundance and localization of PUFA within the context of phospholipid bilayers. Consistent with this concept, addition of arachidonic acid (ARA) or other PUFAs to human cells sensitizes them to ferroptosis (Yang et al. 2016a), presumably because this increases PUFA incorporation into phospholipid membranes.

PUFAs are esterified into membrane phospholipids, especially phosphatidylethanolamine (PE)-containing phospholipids with arachidonate or adrenate moieties, and generate lipid peroxides in membrane phospholipids that cause ferroptotic cell death (Doll et al. 2017; Kagan et al. 2017). Acyl-CoA synthetase long chain family member 4 (ACSL4) and lysophosphatidylcholine acyltransferase 3 (LPCAT3) are enzymes that are necessary for the generation of PUFA-PEs in human and mouse cells, suggesting that ancestral orthologs of genes encoding these enzymes may have played a role in the evolution of ferroptosis (Fig. 1). Deletion of these genes causes resistance to ferroptosis in mammals (Dixon et al. 2015; Yuan et al. 2016; Doll et al. 2017; Kagan et al. 2017).

Some enzymes drive the peroxidation that causes ferroptotic cell death. For example, lipoxygenases (LOXs; encoded by the $A L O X$ genes) mediate ferroptotic cell death in some contexts (Seiler et al. 2008; Yang et al. 2016a; Kagan et al. 2017), suggesting that the evolution of ALOX genes may be coupled to the emergence of ferroptosis and/or novel functions of lipid peroxidation. PEBP1, also known as RKIP1, interacts with LOXs (particularly isoforms of 15-LOX) to modulate their substrate specificity toward PUFA-PE (Wenzel et al. 2017). Thus, evolution and regulation of the PEBP1/RKIP1 gene may be related to the specificity of PUFA-PE peroxidation generated during the execution of the ferroptotic program in nonmammalian species as well. Also, lipid peroxides often decompose into reactive electrophiles, such as aldehydes and Michael acceptors, which can further damage other 
proteins and nucleic acids (Gaschler and Stockwell 2017). The AKR1C genes (Dixon et al. 2014) encode aldoketoreductases that can detoxify these species and may also finetune sensitivity to ferroptosis (MacLeod et al. 2009).

As the term ferroptosis implies, iron is critical for execution of ferroptosis, as it is necessary for lipid peroxidation in iron-dependent oxygenases such as LOXs and as free divalent iron to propagate the peroxidation reaction through Fenton chemistry. A recent study indicates that both enzymatic LOX-catalyzed and nonenzymatic irondependent free radical mechanisms can be engaged in ferroptosis (Shah et al. 2018). As a result, iron metabolism and availability are key contributors to sensitivity to lipid peroxidation and ferroptosis. Relevant genes controlling iron abundance and modulating ferroptosis include transferrin and transferrin receptor, which import iron into cells (Yang and Stockwell 2008; Gao et al. 2015); IREB2, a regulator of iron metabolism (Dixon et al. 2012); and the machinery for degradation of ferritin, known as ferritinophagy (Mancias et al. 2014; Gao et al. 2016; Hou et al. 2016; Wang et al. 2016). Ferritin is recognized by NCOA4 (Mancias et al. 2014), and this gene product also modulates ferroptosis sensitivity in some species.

The mevalonate pathway results in biosynthesis of the lipophilic antioxidant coenzyme $\mathrm{Q}_{10}\left(\mathrm{CoQ}_{10}\right)$ (Shimada et al. 2016b). The compound FIN56 depletes mevalonatederived $\mathrm{CoQ}_{10}$ by modulating squalene synthase (SQS; encoded by the FDFT1 gene) (Shimada et al. 2016b); statin drugs inhibit HMG CoA reductase (HMGCR), also depleting $\mathrm{CoQ}_{10}$ and inhibiting tRNA isopentenylation via TRIT1, needed for maturation of GPX4 (Fradejas et al. 2013; Shimada et al. 2016b; Viswanathan et al. 2017). Ferroptosis sensitivity is also impacted by the NADPH and selenium metabolism pathways (Shimada et al. 2016a; Cardoso et al. 2017) as well as kiss of death (KOD) in Arabidopsis (Distefano et al. 2017). Orthologs of these genes may modulate ferroptosis sensitivity in numerous species.

\section{Ferroptosis and lipid peroxidation in mammals}

Much of what we know today about the in vivo relevance of ferroptosis in mammals comes from in vivo pharmacological studies using the ferroptosis inhibitors liproxstatin-1 and ferrostatin-1 and their analogs in animal models of human diseases or in mice deficient for GPX4 (Fig. 2). A number of studies of ferroptosis and lipid peroxidation have been performed in human and mouse cell lines and in ex vivo models; human genetic and pharmacological data provide additional insights into the functions and regulation of these processes in humans. Nonetheless, the field of ferroptosis is still in many ways at a nascent stage, and much of the evidence for ferroptosis in various models and species is indirect or circumstantial due in part to the limited number of established biomarkers of ferroptosis. In this review, we summarize both where ferroptosis has been definitively identified and where data are suggestive that ferroptosis could be operative. Many of these systems require additional studies to verify or re-

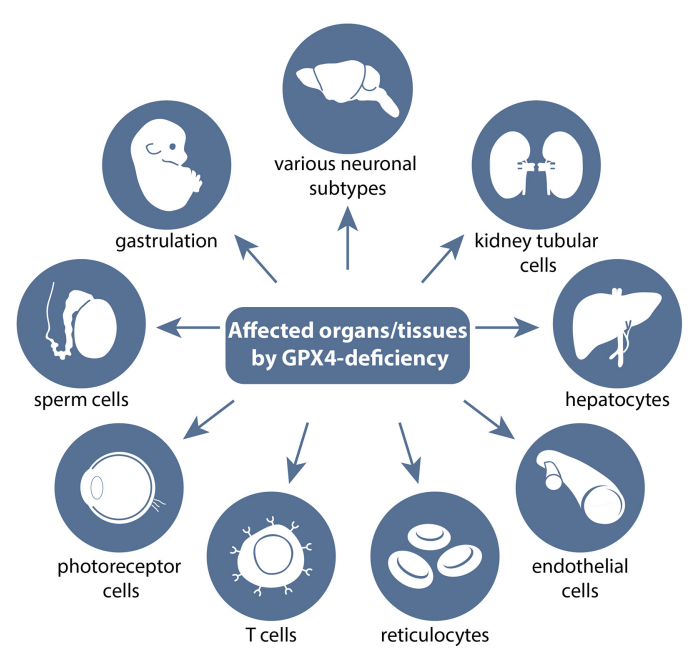

Figure 2. Transgenic studies of GPX4 in mice reveal which tissues are, in principle, sensitive to undergoing ferroptosis. A myriad of transgenic studies performed in mice have pinpointed which cells and tissues depend on a functional glutathione/ GPX4 system and thus in general are susceptible to ferroptotic cell death. A number of knockout studies with systemic deletion of the Gpx4 gene showed that loss of GPX4 causes early embryonic lethality around the gastrulation stage (i.e., embryonic day 7.5 [E7.5]). Beyond its requirement in early embryogenesis, several conditional deletion approaches of $G p \times 4$ in different neuronal subpopulations revealed its necessity for a number of different neurons, such as pyramidal cells in the hippocampus, glutamatergic neurons in the cerebral cortex, cerebellar Purkinje cells, and motor neurons. Tamoxifen-inducible whole-body deletion of Gpx4 showed that kidney epithelial tubular cells are the limiting factor for survival of adult mice. Loss of GPX4 in hepatocytes and endothelial cells showed that in some tissues, Gpx4 deficiency can be compensated for by dietary vitamin E supplementation. Additional tissue-specific knockout studies for $G p \times 4$ pinpointed that reticulocytes, certain $T$ cells, photoreceptor cells, and male germ cells do depend on a functional GSH/GPX4 system. For further details, see the text.

fute the notion that ferroptosis is a relevant cell death mechanism.

\section{Genetic studies addressing the function of GPX4 in mice}

Studies performed in the early years of this century provided independent and conclusive evidence that the constitutive deletion of the mouse $G p_{x} 4$ gene is incompatible with life (Fig. 2). Mice homozygous null for $G p_{x} 4$ develop normally until embryonic days 6.5-7.0 (E6.5-E7.0) but thereafter present overall malformations and thus become resorbed at the gastrulation phase (Imai et al. 2003; Yant et al. 2003). Ttpa ${ }^{-/}$mice lacking vitamin E similarly die between E6.5 and E13.5. Likewise, mice expressing a redox-inactive GPX4 mutant with a targeted replacement of the catalytically active selenocysteine (Sec) by serine or alanine, respectively, also fail to develop beyond gastrulation (Brutsch et al. 2015; Ingold et al. 2015), indicating that a redox-active enzyme is required for normal embryonic development. 
However, the molecular underpinnings causing embryonic death of such knockout/mutant embryos still remain obscure. While one study reported an increase of TUNELpositive cells in homozygous knockout embryos (Imai et al. 2003), others failed to detect changes in the number of dying cells (Yant et al. 2003; Seiler et al. 2008; M Conrad, unpubl.). BrdU-labeling experiments did not reveal any changes in the proliferation rates between wild-type and knockout embryos (Yant et al. 2003), and hyperplasia of embryonic structures was noticed in another study (Seiler et al. 2008). Therefore, perturbed redox-regulated growth factor receptor signaling might lead to abnormal development and patterning of homozygous Gpx4 mutant embryos. In line with this, fibroblasts with inducible Gpx4 disruption showed strong platelet-derived growth factor $\beta$ receptor-dependent cellular responses mediated by an increased steady-state oxidation and inactivation of counteracting protein tyrosine phosphatases (Conrad et al. 2010). Perturbation of such redox-dependent signaling cascades may affect early developmental processes during embryogenesis, including patterning and organogenesis.

The essentiality of $G p \times 4$ in mouse development does not necessarily imply that $G p \times 4$ is essential in all cells and tissues in mice. The introduction of conditional knockout mouse models for Gpx4 has helped to pinpoint which cells and tissues require GPX4 enzymatic activity and which are, in principle, sensitive to undergoing ferroptotic cell death (Fig. 2). Early studies with neuron-specific Gpx4 ablation using CamKIIa-Cre mice revealed that certain neuronal subpopulations, including pyramidal cells of the hippocampus and some inhibitory interneurons, are exceedingly vulnerable to $G p \times 4$ deletion-mediated cell death, which is presumably ferroptosis, although the term had not been introduced at the time (Seiler et al. 2008). As these mice display ataxia and seizures, the selective loss of parvalbumin (PV)-positive GABAergic interneurons in the hippocampus and somatosensory cortex likely explains the overall phenotype of neuron-specific Gpx4-null mice (Seiler et al. 2008; Wirth et al. 2010).

In this context, a recent study by the Conrad laboratory (Ingold et al. 2018) demonstrated that mice with targeted replacement of the active site Sec by cysteine (GPX4-Cys) are born normally but fail to survive beyond 2-3 wk of age. Histopathological analysis revealed a selective loss of $\mathrm{PV}^{+}$ interneurons as the underlying mechanism causing severe spontaneous epileptic seizures of homozygous mutant mice. Hence, it emerged that precisely these specialized interneurons require selenium-containing GPX4 for development and survival, thus representing the limiting factor for murine life.

Ex vivo studies using mouse embryonic fibroblasts with tamoxifen-inducible $G p \times 4$ disruption (now commonly referred to as Pfal cells) or cultured cortical neurons from mutant E15.5 embryos provided early evidence that Gpx4 deletion causes a novel form of nonapoptotic cell death coincident with lipid peroxidation that can be fully prevented by the lipophilic antioxidant vitamin E (Seiler et al. 2008), consistent with the death mechanism being ferroptosis. Meanwhile, a series of additional conditional knockout studies in the brain showed that GPX4 is essential in the cerebellum by preventing Purkinje cell loss and sustaining proper granule cell proliferation (Wirth et al. 2014). The inducible loss of GPX4 in the forebrain was shown to cause progressive cognitive impairment and increased ferroptosis of pyramidal neurons in the CA1 region of the hippocampus, leading to augmented neuroinflammation (Hambright et al. 2017). Like cortical and cerebellar neurons, motor neurons, which progressively die in patients suffering from amyotrophic lateral sclerosis (ALS), are equally sensitive to $G p \times 4$ knockout-induced cell death (Chen et al. 2015). In this context, it is worth mentioning that patients suffering from ALS or frontotemporal dementia (FTD), a neurodegenerative disease affecting neurons of the frontal or temporal lobes, share many genetic traits (Ling et al. 2013).

However, not all neuronal subpopulations are equally sensitive to Gpx4 loss. The selective disruption of Gpx4 in POMC (proopiomelanocortin) neurons or AgRP (agouti-related protein) neurons of the hypothalamus or dopaminergic neurons of the ventral midbrain did not impact the viability of these specialized neurons (Schriever et al. 2017). This may be due to different redox systems compensating for GPX4 loss; different metabolic constraints, including vitamin $\mathrm{E}$ and ubiquinone utilization; different phospholipid metabolism; or different expression of lipid-modulating enzymes, such as ACSL4 or LPCAT3. Photoreceptor cells strongly depend on functional GPX4 (Ueta et al. 2012), which might be explained by their permanent exposure to photo-oxidative stress as well as high demand for ATP, high metabolic activity, and high rate of reactive oxygen species (ROS) generation. Besides central nervous system (CNS) neurons, motor neurons, and photoreceptor cells, a number of other cells and tissues absolutely require functional GPX4.

Kidney tubular cells are highly dependent on GPX4 for survival, which is the limiting factor for adult mouse survival when GPX4 is disrupted in a 4-hydroxy-tamoxifen (TAM)-inducible manner in adult mice using the ROSA26_CreERT2 deleter mouse (Friedmann Angeli et al. 2014). While the loss of GPX4 in this model was efficient and detectable in many peripheral tissues (except the brain), massive cell death of kidney-proximal tubule cells caused acute renal failure and death of mice $~ 10$ $12 \mathrm{~d}$ after knockout induction. Remarkably, the histopathological phenotype of these mice is highly reminiscent of what is observed during delayed graft function (DGF) upon kidney transplantation in humans. As these cells are metabolically active and have an extremely high demand for ATP, it follows that they are extremely sensitive to ischemia/reperfusion (IR) events as occurring upon kidney transplantation.

In male germ cells, the picture of GPX4 dependence is complex. While the spermatocyte-specific knockout of Gpx4 removes all three isoforms of GPX4 protein (short/ cytosolic, mitochondrial, and nuclear), tissue-specific knockout is associated with oligospermia, increased cell death of germinal cells, and, consequently, male infertility (Ueta et al. 2012). Isoform-specific loss of the nuclear or mitochondrial isoforms of GPX4 provokes specific defects 
in sperm development (Conrad et al. 2005; Schneider et al. 2009). However, only in the case of the mitochondrial isoform was male infertility detected (Schneider et al. 2009), which is not due to an effect on cell survival but GPX4's unique role to act as a thiol peroxidase in sperm cells.

Deletion of $G p_{x} 4$ in hematopoietic cells in mice using Mx1-Cre mice is associated with mild anemia, compensated for by erythropoietin (EPO)-induced reticulocyte proliferation and extramedullary erythropoiesis in the spleen (Canli et al. 2016). Curiously, RIPK3 (receptorinteracting serine/threonine kinase 3)-mediated necroptosis, rather than ferroptosis, was found to underlie the mild anemia in these tissue-specific $G p \times 4$ knockout mice.

Increased lipid peroxidation in response to T-cell-specific $G p \times 4$ ablation has adverse effects on T-cell immunity, as the number of peripheral $\mathrm{CD}^{+} \mathrm{T}$ cells as wells as splenic $\mathrm{CD}^{+}$and $\mathrm{CD}^{+} \mathrm{T}$ cells is greatly reduced in T-cell-specific Gpx4 knockout mice (Matsushita et al. 2015). These effects were even more pronounced when these mice were challenged with viral and parasitic infections, such as lymphocytic choriomeningitis virus (LCMV) and Leishmania major, respectively, causing widespread ferroptosis of $\mathrm{T}$ cells. Dietary supplementation with high concentrations of vitamin E $(500 \mathrm{mg} / \mathrm{kg})$, a ferroptosis suppressor, was able to restore all of the defects, including viral clearance. A similar relation between dietary vitamin E content and the loss of GPX4 holds true for endothelial cells, hepatocytes, and, as noted above, hematopoietic cells.

Knockout of $G p_{x} 4$ in the endothelium has no overt effect on the survival of mice (Wortmann et al. 2013). Only when these mice were kept on a low vitamin E diet was endothelial cell death shown to cause thrombus formation and microinfarcts in multiple organs, such as the kidney and heart, causing premature death of the animals. Conversely, hepatocyte-specific knockout mice (when mothers were kept on the National Institutes of Health-recommended diet with $\sim 45 \mathrm{IU} \mathrm{mg} / \mathrm{kg}$ vitamin E) died perinatally due to massive liver necrosis (Carlson et al. 2016). Feeding mothers with high amounts of vitamin $\mathrm{E}$ in the diet allowed hepatocyte-specific knockout mice to survive. These effects are reversible, as the removal of vitamin E again triggers liver necrosis and death of liver-specific knockout mice (Carlson et al. 2016). Similarly, removing vitamin $\mathrm{E}$ from the diet aggravated the anemia observed in hematopoietic-specific $G p \times 4$ knockout mice. Hence, all of these studies call for a careful examination of the diets used in experimental studies addressing ferroptosis in both transgenic animal models and other mouse models using pharmacological approaches with ferroptosis modulators.

\section{In vivo pharmacological analysis of ferroptosis in animal models of disease}

There are two main classes of potent ferroptosis inhibitors (ferrostatins and liproxstatin-1) that have been evaluated in a number of mouse models of human disease. The combination of 16-86 (a derivative of ferrostatin-1), necrostatin-1, and Sanglifehrin A proved to be highly protective in a mouse model of transient IR injury (IRI) in the kidney (Linkermann et al. 2014). In a similar setting, liproxstatin1 was reported to ameliorate hepatic damage induced by IR in wild-type mice and delay acute renal failure and associated death by TAM-inducible GPX4 disruption in adult mice (Friedmann Angeli et al. 2014).

In the CNS, liproxstatin ameliorated neuronal loss and associated astrogliosis in mice lacking $G p_{X} 4$ in the forebrain (Hambright et al. 2017). When tested in mouse models of intracerebral hemorrhage (ICH), intracerebroventricular administration of either ferrostatin or liproxstatin was able to reduce the number of degenerating neurons, thereby improving neurologic deficit as an outcome (Li et al. 2017). Both compounds, when applied intranasally, also strongly reduced the extent of transient middle cerebral artery occlusion (MCAO)-induced focal cerebral IRI, a model widely used to mimic stroke (Tuo et al. 2017). Hence, it emerged that IRI events and neurodegenerative diseases may benefit from anti-ferroptotic strategies, although CNS penetration needs to be assessed for such compounds in each model.

Ferroptosis inhibitors have also been shown to be highly protective in organoid/ex vivo models, including slice cultures of the rat brain, isolated hearts, and a great number of human and murine cell lines undergoing ferroptosis, further highlighting the potential of ferroptosis inhibitors for the treatment of degenerative diseases (Angeli et al. 2017). However, these studies need to be taken with care and should be validated in animal models of disease. This is due to the fact that the redox environment in tissue culture conditions and plasma and other extracellular fluids in whole organisms varies greatly (Leist et al. 1996). This is best illustrated by the fact that mice genetically lacking a substrate-specific subunit of system $\mathrm{X}_{\mathrm{c}}{ }^{-}, \mathrm{xCT}$ (Slc7a11), are fully viable (Sato et al. 2005), while most cell lines derived therefrom die within $1 \mathrm{~d}$ in culture (Conrad and Sato 2012). The underlying reason is that the bulk of cysteine in the culture medium is not present in its reduced but oxidized form (i.e., cystine), which can be taken up in cell culture only by system $\mathrm{X}_{\mathrm{c}}{ }^{-}$. In stark contrast, in $\mathrm{xCT}$-null mice, there is still a considerable amount of reduced cysteine present in extracellular fluids, which can be easily taken up by cells by the so-called neutral amino transporter ACST, thereby bypassing the need for $\mathrm{xCT}$ in vivo. However, some tumors appear to become addicted to $\mathrm{xCT}$, as evidenced by their sensitivity to $\mathrm{xCT}$ inhibitors in vivo (Ishimoto et al. 2011; Cramer et al. 2017).

\section{Circumstantial evidence for ferroptosis in humans}

Several lines of evidence suggest that some human tissues may be sensitive to ferroptosis. The Food and Drug Administration (FDA)-approved multikinase inhibitor sorafenib was reported to inhibit system $\mathrm{X}_{\mathrm{c}}{ }^{-}$and induce ferroptosis along with a nonferroptotic cell death in cell culture models (Louandre et al. 2013; Dixon et al. 2014; Lachaier et al. 2014). Analysis of adverse events associated with sorafenib in patients revealed that compared with other multitargeted kinase inhibitors with similar target 
kinase profiles that do not inhibit system $\mathrm{X}_{\mathrm{c}}{ }^{-}$or induce ferroptosis, sorafenib induces a unique and larger profile of adverse events, suggesting that it exerts an additional activity in patients, consistent with its unique ability to inhibit system $\mathrm{X}_{\mathrm{c}}{ }^{-}$(Dixon et al. 2014).

Statin drugs have been reported to sensitize cells in culture to ferroptosis and induce ferroptosis in some cell lines (Shimada et al. 2016b; Viswanathan et al. 2017). Patients treated with statins have lower tumor incidence, suggesting that statins may exert a tumor-suppressive effect in patients through driving ferroptosis in nascent tumor cells (Mullen et al. 2016); of course, statins have diverse effects downstream from HMGCR inhibition, so additional studies are needed to examine whether ferroptosis is a clinically meaningful effect of statins.

Acetaminophen is widely used to treat pain and fever in humans. Acetaminophen is metabolized to N-acetylp-benzoquinone imine (NAPQI), which reacts with glutathione and can trigger glutathione depletion and ferroptosis in primary mouse hepatocytes (Lorincz et al. 2015). The liver failure seen in patients who overdose on acetaminophen may thus be exacerbated by liver ferroptosis and perhaps could be prevented by ferroptosis inhibitors. However, in vivo studies are needed to extend this hypothesis from the limited cell culture experiments that have been consistent with this idea.

In a recent report, high-resolution large area confocal immunofluorescence microscopy demonstrated the colocalization of 15-LOX-1 with PEBP1 in fresh human airway epithelial cells obtained by bronchoscopic brushing of patients with controlled nonexacerbating asthma (Wenzel et al. 2017). Notably, a strong correlation $\left(r^{2}=\right.$ 0.98 ) was established between the number of colocalized PEBP1/15LO1 puncta in the freshly brushed airway epithelial cells and the fractional exhaled nitric oxide (FeNO), a marker of T2 inflammation. This suggests that PEBP1/15-LOX-1-dependent peroxidation of AA-PE is important in $\mathrm{T} 2$ airway inflammation associated with asthma. Furthermore, PUFA-PE oxidation products characteristic of ferroptosis were detected in cell pellets from urine samples obtained from patients enrolled in the Biologic Markers of Recovery for the Kidney (BioMaRK) study at the time of initiation of dialysis (Wenzel et al. 2017). The levels of these PE oxidation products were increased in patients with acute kidney injury who did not recover renal function (defined as persistent dialysis requirement) versus patients who recovered renal function regardless of the etiology of AKI (sepsis or not).

Some humans have mutations in GPX4 that are associated with the Sedaghatian type of spondylometaphyseal dysplasia (Smith et al. 2014), which is a lethal disorder characterized by short stature, limb shortening, pulmonary hemorrhage, delayed cartilage formation, and early death. While the pathological consequences of these mutations are not known, they may cause induction of ferroptosis in such patients due to diminished GPX4 activity.

Rare mutations in SBP2 reduce the efficiency of selenium uptake and utilization (Schoenmakers et al. 2010). Since GPX4 is a selenoprotein, SBP2 mutations would be expected to impair GPX4 function; indeed, fibroblasts from such patients are reported to exhibit elevated lipid peroxidation (Schoenmakers et al. 2010). While ferroptosis per se has not been observed in these individuals, some of the pathologies of SBP2 deficiency may be caused by ferroptosis.

\section{Lipid peroxidation and cell death in nonmammalian vertebrates}

Egg-laying vertebrates are classified as nonmammalian, where the egg serves as a specialized system for the propagation of the animal. Embryonic growth is completely contained within this semiclosed system that provides nutrients that are maternally derived and enclosed in the egg upon its laying. Lecithotrophs, such as zebrafish, chicken, and other egg-originating organisms, rely on fatty acid reservoirs and endogenous antioxidant buffers for embryo viability (Parolini et al. 2017). Sequestration of nutrients by the growing embryo is tightly regulated for properly timed metabolic functions (Dutta and Sinha 2017). Additionally, egg-laying species have increased embryonic metabolic rates concomitant with increased oxidative stress, suggesting greater propensity for critical fatty acid species peroxidation (Deeming and Pike 2013).

Inside the egg yolk, long chain PUFAs, essential to neurodevelopment, are readily available but inherently susceptible to heightened oxidative damage. Specifically, docosahexaenoic acid (DHA) and ARA account for the largest concentration of fatty acids in the developing vertebrate brain but also contain multiple bis-allylic carbons prone to peroxyl radical formation. Oxidized phospholipid ARA is proinflammatory and associated with eicosanoid signaling in zebrafish injury models (Enyedi et al. 2016).

A basic difference between oviparous species and mammals is that the egg barrier regulates diffusion of gases across avian calcified shells and aquatic chorions (Seymour and Wagner-Amos 2008; Pelka et al. 2017). Oxygen diffuses across the poultry shell membrane at rates proportional to partial pressure between the egg and environment, depending on the number and size of pores and the shell composition (Wagner-Amos and Seymour 2002). Birds and reptiles are adapted for terrestrial growth, with the allantois and amniotic membranes that provide additional gas exchange protection. Egg shell traits are specific to habitat, demonstrated by the high-altitude gray gull (Larus modestus), which trades oxygen diffusion and hypoxic potential for enhanced water conservation (Monge et al. 2000). Similarly, localized shell permeability is associated with altered yolk sac development and vascularization in gekkotan lizards (Andrews et al. 2013). Thus, in ovo development requires ample metabolic and morphological adaptations to prevent ROS-induced cell damage (Taylor et al. 2004; Ibrahim et al. 2007; Smith et al. 2014).

\section{Protective anti-ferroptotic adaptations in the egg}

Eggs are enriched in nutritionally derived and maternally allocated lipophilic antioxidants to protect against the rise of peroxyl radicals and lipid hydroperoxide generation 
(Kim et al. 2013; Giraudeau and Ducatez 2016). Although antioxidant concentrations depend on diet, eggs contain an easily manipulated range of fat-soluble antioxidants that effectively scavenge hydroxyl and peroxyl radicals. Chicken mothers furnish their eggs with a-tocopherol, a lipophilic chain-breaking antioxidant and nature's lipidsoluble radical-trapping antioxidant (Surai et al. 1999; Surai 2000); selenium, a key component of antioxidant selenoproteins such as GPX4 (Tapiero et al. 2003); and numerous protein hydrolysates that confer enhanced antioxidant activity compared with intact proteins (Davalos et al. 2004; Xu et al. 2007; Liu et al. 2014). Uptake of these nutrients during embryonic development is also critically important. For example, a-tocopherol transfer protein (TTP) expression determines $\alpha$-tocopherol bioavailability in the zebrafish embryo CNS (Miller et al. 2012).

ROS generated during embryogenesis signal cellular proliferation and tissue differentiation; however, imbalanced production of these species by endogenous metals and lack of antioxidants may lead to a risk of developmental abnormalities and cell death. During zebrafish embryogenesis, vitamin E-deficient embryos experience increased lipid peroxidation (McDougall et al. 2016, 2017) and a lethal dysregulation of energy metabolism (e.g., an antiWarburg effect) (Maldonado 2017; McDougall et al. 2017). These vitamin E-depleted embryos display a mitochondrial metabolic reprogramming that shunts glucose to the pentose phosphate pathway for NADPH production, ultimately increasing nonaerobic glycolysis, depleting glucose, and increasing morphological malformations (McDougall et al. 2017). Thus, a metabolic switch occurs between 24 and $48 \mathrm{~h}$ post-fertilization (hpf), with the deficient embryo switching from high to low oxygen consumption with concomitant decreases in glutathione and NADPH (McDougall et al. 2017). Furthermore, vitamin E insufficiency-linked dysmetabolism is associated with both lipid peroxidation and secondary glucose deficiency, as evidenced by partial neurological rescue with glucose injections (McDougall et al. 2017). Thus, vitamin $\mathrm{E}$ is essential for zebrafish development, although this has not been attributed to ferroptosis.

Early exposure to excess toxins when the zebrafish embryonic chorion is just forming may have a significant impact on long-term neurological development in vertebrates (Gellert and Heinrichsdorff 2001). Some oviparous species predispose their young to excretion of metals in both the egg shell and contents (Burger 1994; Skrivan et al. 2005). Metal-initiated oxidative stress in the developing animal disrupts long chain PUFA synthesis (Monroig et al. 2009), negatively affects mitochondrial genome stability (Guérin et al. 2001), and down-regulates transsulfuration and remethylation pathways (Dalto and Matte 2017). Additionally, iron accumulation in avian reproductive organs decreases egg production (Yang et al. 2008). Such iron accumulation would likely sensitize these embryos to ferroptosis triggers.

The egg is defended from iron-related oxidative insults with the added protection of the antioxidant enzymes ovalbumin and ovotransferrin (Nimalaratne and Wu 2015; Oladipo and Ibukun 2017). Ovalbumin contains free thiol groups that allow it to act synergistically with other thiolcontaining enzymes as redox buffers and radical quenchers (Goto and Shibazaki 1971; Sun et al. 2006). Ovotransferrin, as the name implies, displays metal ion binding with a preference toward iron and is a major egg white protein, protecting the developing embryo with superoxide dismutase-like activity (Ibrahim et al. 2007). Crocodilian ovotransferrin has more iron-binding sites compared with that of birds and fish, which may be a selective consequence of laying eggs in iron-rich soils (Chaipayang et al. 2017). Perhaps this indicates a danger of ferroptosis in the developing crocodile embryo.

Other egg-related antioxidant enzymes include lysozyme, nitric oxide inhibitor cystatin, and metal-binding phosvitin (Ishikawa et al. 2004; Nimalaratne and Wu 2015). Oviparous fish similarly deposit vitellogenin and phosvitin, major yolk proteins that scavenge free radicals attributable to phosphoserine protein structure and ironchelating capacity (Hu et al. 2015). Redox homeostasis critically hinges on GPXs and glutathione de novo synthesis, demonstrated by localization of the enzymes in the yolk and increasing expression in critical tissues such as the brain, liver, and kidney during development (Glisic et al. 2015; Mendieta-Serrano et al. 2015). Thus, the egg is protected by a wealth of antioxidants and iron regulatory mechanisms to reduce the harmful effects of oxidative stress in embryogenesis, some of which may involve ferroptosis and lipid peroxidation.

\section{Mitochondria in the zebrafish egg and developing embryo}

During zebrafish oogenesis, mitochondria disperse in specific patterns in the yolk, possibly as a marker of oocyte quality and metabolic function (Zhang et al. 2008). In the first $24 \mathrm{hpf}$, deficiencies in vitamin E are associated with dysregulated mitochondrial oxidative phosphorylation and TCA cycle metabolites (McDougall et al. 2017). In zebrafish development and aging, mitochondrial metabolism is critical in maintaining cellular redox balance and preventing ferroptosis (Osellame et al. 2012), as metabolic reprogramming to counter ROS increases glucose catabolism and cellular acidification (Lamonte et al. 2013). The cellular environment reacts in a feed-forward manner to decrease $\mathrm{pH}$, increase ferric iron solubility, and amplify cellular lipid peroxidation (Schafer and Buettner 2000). Disturbed mitochondrial membrane permeability and electron transport chain (ETC) integrity damaged by oxidants are also detrimental to zebrafish (Cambier et al. 2009, 2012; Kim et al. 2013; Ren et al. 2016). ETC iron-sulfur cluster protein synthesis appears necessary to prevent redox-related dysfunction in zebrafish steroidogenesis (Ewen et al. 2011; Griffin et al. 2016). While the function of mitochondria in ferroptosis in mammals is ambiguous, the critical function of mitochondria and lipid peroxidation in developing zebrafish suggests a possible link in fish.

\section{Glutathione and glutathione-dependent peroxidases}

Ferroptosis is prevented by adequate glutathione, GPX4, and NADPH (Maiorino et al. 2017). As noted above, the 
selenium-containing enzyme GPX4 (Brigelius-Flohe and Maiorino 2013) acts by reducing lipid hydroperoxides (Yang et al. 2014). Lack of protection from lipid peroxidation, such as in selenium deficiency, causes exudative diathesis in broiler birds (Cao et al. 2017). Depletion of GPX4 may be the cause of this selenium deficiency disease (Yao et al. 2014).

GPX4 activity in the brain has been used as a marker for ferroptosis and neurodegeneration (Cardoso et al. 2017): Increased lipid ROS and cell death in zebrafish gills upon cold shock were abrogated by the antioxidant cascade of $\mathrm{Cu} / \mathrm{Zn}$ superoxide dismutase (SOD), catalase (CAT), and GPX activity (Wu et al. 2015). Selenium deficiency and the resultant loss of selenoprotein activities correlate with increased oxidative stress, metal ion imbalance (Yao et al. 2017), and cell death (Peng et al. 2012) in production poultry. Reduced glutathione utilization and GPX activity in selenium-deficient broiler brains disrupts mitochondrial membrane integrity, shifting calcium balance, a marker of neurodegeneration (Xu et al. 2013). Inhibition of these thiol-containing molecules induces histological damage and the lipid peroxidation marker malondialdehyde (MDA) in zebrafish gonads (Zhang et al. 2016). Thiol-containing antioxidant protein production is important in maintaining cellular redox balance and lipid health from embryo to adult but may not be sufficient (Glisic et al. 2015). Nuclear factor erythroid 2-related factor (Nrf2) signaling up-regulates cellular antioxidant capacity through glutathione-related gene expression but was unable to mitigate the oxidative stress associated with transportation or heat stress in brains from production poultry (Chowdhury et al. 2014; Ge et al. 2017). Maternal vitamin E supplementation in vertebrates prevents GPX4 knockdown-induced lethality in offspring (Carlson et al. 2016), similar to the situation in mammals.

Choline depletion is a significant secondary effect of lipid peroxidation in vitamin E-deficient zebrafish embryos (McDougall et al. 2016, 2017); choline is depleted at all time points between 24 and 120 hpf (McDougall et al. 2016,2017 ) when vitamin $\mathrm{E}$ is lacking in zebrafish embryos. Choline is essential for one-carbon metabolism (Zeisel 2013); e.g., transfer of one-carbon units through folate intermediates for use in purine and thymidylate synthesis, $\mathrm{NADP}^{+} / \mathrm{NADPH}$ production, and other methylation reactions (e.g., epigenetic regulation by DNA methylation) (Zeisel 2017).

Choline is converted into betaine to provide one-carbon units for remethylation of homocysteine to methionine (Yang et al. 2016a). Dietary choline restriction compromises energy status and causes a rapid onset of oxidative stress in the liver (Hensley et al. 2000). This can result in depletion of NADPH as a side effect of choline restriction. Ultimately, inadequate antioxidant protection causes lipid peroxide-induced cellular damage, including vitamin E depletion connected with early-onset encephalomalacia in young chickens (Lin et al. 2005) and zebrafish embryos or adults fed vitamin E-deficient diets (Lebold et al. 2013; Choi et al. 2015). Fish raised with deficiencies in vitamin E (McDougall et al. 2017) also develop abnor- mally, demonstrating the necessity of peroxyl and hydroxyl radical scavengers for cell and organismal health.

\section{Role of iron and metals in cellular damage to vertebrates}

Cellular iron is essential for life. Excess catalytic loosely chelated Fe(II) can be cytotoxic (Ito et al. 2016). To prevent iron-associated damage, cytosolic and mitochondrial ferritin protein chelate iron in the hypothalamic-pituitarygonadal (HPG) axis of laying geese, contributing to avian reproductive success (Kang et al. 2015). Ferritin in rayfinned fish is equally important in defending against catalytic iron-induced damage, as observed in the big belly seahorse (Furlong et al. 2000), yellow snapper (ReyesBecerril et al. 2014), and channel catfish (Liu et al. 2010).

Phosvitin inhibits ferric iron-catalyzed phospholipid oxidation with impressive chelating potential, binding more iron than ferritin in avian eggs (Lu and Baker 1986; Ishikawa et al. 2004). Metallothioneins also protect susceptible tissue from metal-induced oxidative damage in the gills of zebrafish (Wu et al. 2016). Iron not sequestered by binding proteins or chaperoned out of the cell by ferroportin can propagate chain reactions of lipid peroxidation through Fenton chemistry. Gulls demonstrate the ability to suppress ferroptosis by up-regulating iron storage and transfer proteins (ferroportin and transferrin) and increasing glutathione recovery (Jenko et al. 2012).

Iron-containing nanoparticles used to initiate the Fenton reaction induce genotoxic stress in zebrafish endocrine tissue (Ahmad et al. 2016) and guppy erythrocytes (Qualhato et al. 2017). Defects in ferroportin expression, which limit extracellular iron release, cause iron storage disease and promote lipid peroxidation in avian liver, heart, and spleen (Cork 2000; Pavone et al. 2014). Iron-dependent cell damage is also observed in Japanese quail (coturnix japonica), where extracranial arterial atherosclerotic injury with increased levels of both catalytic iron and heme oxygenase-1 (HO-1) activity positively correlates with oxidized lipids and lipoprotein accumulation (Hoekstra and Velleman 2008).

Mitochondria are increasingly viewed as important for iron regulation because of their role in iron sequestration, especially in tissue with high metabolic activity and risk of Fenton chemistry (Santambrogio et al. 2007). The avian liver, a primary hub of lipid metabolism and metal detoxification, demonstrates an intrinsic susceptibility to irondependent cell death (Cork 2000; Schafer and Buettner 2000), which may involve ferroptosis. Even normal levels of redox-active metals can have negative consequences on antioxidant function during hypoxia, leading to mitochondrial dysfunction and cell death (Braga et al. 2016). Altered antioxidant and iron storage predispose the cell and organelles to insults from oxidative stress catalyzed by ferric iron, some of which may involve ferroptosis.

\section{Possibilities for ferroptosis in nonmammalian vertebrates}

Like humans, zebrafish cannot synthesize ascorbic acid and require this dietary vitamin in the form of adequate 
intake of vitamin C (Kirkwood et al. 2012). Zebrafish share with humans the ability to elongate PUFAs from essential fatty acids (e.g., linoleic [18:2] and linolenic [18:3] acids) and have the same major pathways for lipid synthesis, trafficking, and metabolism (Babin and Vernier 1989; Holtta-Vuori et al. 2010). Zebrafish mothers synthesize long chain PUFAs and determine the egg PUFA composition, with eggs enriched in DHA and ascorbic acid. Thus, zebrafish embryos are useful for studies of the role of lipid peroxidation. Aberrant lipid peroxidation has been described as detrimental to successful poultry husbandry through reduced fertility (Rui et al. 2017), chick hatchability (Surai et al. 1999), and microsomal and mitochondrial health (Gutierrez et al. 2002, 2004). Chickens are a clear example where selenium deficiency causes muscular dystrophy associated with lipid peroxidation, suggesting a role for ferroptosis (Yao et al. 2014).

Nonmammalian vertebrates exhibit iron-mediated lipid peroxidation in all stages of life, although the extent to which ferroptosis per se is involved remains unknown in most cases. These animals also serve as critical components of our natural ecosystems and agricultural systems and are valuable as model organisms in a number of biomedical fields. With pathologies related to dysregulated iron homeostasis, lipid peroxidation, and depletion of major antioxidant networks, nonmammalian vertebrates will likely continue to serve as valuable systems for the study of ferroptotic cell death.

\section{Ferroptosis-like cell death in plants}

Regulated cell death is an integral part of the plant life cycle and plays a critical role during vegetative and reproductive development. Essential developmental programs such as megasporogenesis, pollen development, fertilization, embryogenesis, xylem element development, and leaf shape regulation rely on specific cell death events (Gunawardena et al. 2004; Drews and Koltunow 2011; Bollhoner et al. 2012; Choi 2013; Xie et al. 2014). Regulated cell death is also crucial for plant-specific responses to external stimuli: Diverse environmental stresses such as salt stress, drought, and nutrient starvation can induce cell death in plants (Huh et al. 2002; Liu et al. 2009; Duan et al. 2010). In addition, the hypersensitive response (HR), a localized type of cell death, is triggered at the site of the attack during incompatible plant-pathogen interactions.

Plant cells use specific cell death pathways that are intimately related to plant structures. For instance, plant cells do not undergo apoptosis, as measured using classic morphological features observed in animal cells. The rigid plant cell wall also prevents plant cells from breaking into apoptotic bodies, and even when protoplasts are known to shrink in response to diverse abiotic stresses, they do not further fragment into discrete bodies. A large vacuolar system occupies most of the plant cell volume (Marty 1999); these large vacuoles have important functions during a plant-specific type of cell death (termed vacuolar cell death) that involves a gradual decrease in the cytoplasm volume and formation of small lytic vacuoles (Jones 2001).
Several Arabidopsis autophagy (ATG) genes have been implicated in plant vacuolar cell death and were first identified based on sequence similarity to yeast autophagy genes (Xie and Klionsky 2007). Mitochondria and other plant organelles remain intact until the final stages of vacuolar cell death, which involves tonoplast rupture, disassembly of the nuclear envelope, and nuclear segmentation (van Doorn et al. 2011). Vacuolar cell death is also associated with several developmental pathways, including aerenchyma formation, leaf remodeling, and xylem differentiation (Drew et al. 2000; Gunawardena et al. 2004; Courtois-Moreau et al. 2009), and has also been linked to plant responses to multiple environmental stress conditions and leaf senescence (Liu et al. 2009; Kariya et al. 2013).

Although plant cell death can be triggered by several insults and during developmental programs, accumulation of ROS is a common feature of many plant pathways (Van Breusegem and Dat 2006; Doyle et al. 2010; Xie et al. 2014). It was reported more than a decade ago that ascorbic acid and glutathione depletion are linked to ROS accumulation and cell death during HR and senescence (Senda and Ogawa 2004; Pavet et al. 2005; Noctor et al. 2012), although the significance of this association was not known.

As noted above, ferroptosis is defined as a form of cell death that is accompanied by lipid peroxidation and can be suppressed by iron chelators and lipophilic antioxidants (Stockwell et al. 2017). Ferroptosis can also be prevented in mammalian cells by inhibitors of lipid peroxidation or depletion of PUFA phospholipids via genetic inactivation of ACSL4 or LPCAT3. While NADPH oxidase (NOX) and LOXs act as positive regulators of ferroptosis, GPX4 functions as a negative regulator (Dixon et al. 2012; Yang et al. 2014; Yang et al. 2016a). LOX-dependent lipid peroxidation is associated with cell death in plants during the HR (Montillet et al. 2005; Zoeller et al. 2012). While the occurrence of an oxidative burst, antioxidant depletion, and LOX activation is a hallmark of ferroptosis, it was not until quite recently that these events were linked to a ferroptosis-like form of cell death in plants (Fig. 3; Distefano et al. 2017).

Exposure of Arabidopsis thaliana root hairs to $55^{\circ} \mathrm{C}$ heat shock triggers a cell death process that can be prevented by the iron chelator ciclopirox (CPX) or the lipophilic antioxidant ferrostatin-1 (Distefano et al. 2017). These inhibitors have no effect on root hair cell death in response to salt stress, higher temperatures that induce necrosis, or hydrogen peroxide or on programmed cell death related to vascular or reproductive development, suggesting that $55^{\circ} \mathrm{C}$ heat shock induces a specific ferroptotic-like cell death in plants. Notably, many of the morphological hallmarks that characterize ferroptosis in animal cells are conserved in plants exposed to heat stress. Dying cells showed a retracted cytoplasm, probably due to vacuolar disruption; normal nuclei; and shrunken mitochondria (Fig. 3).

Heat shock $\left(55^{\circ} \mathrm{C}\right)$ results in glutathione and ascorbic acid depletion and intracellular ROS accumulation through increased NOX activity and lipid peroxidation. While ROS accumulation can be prevented by pretreating 


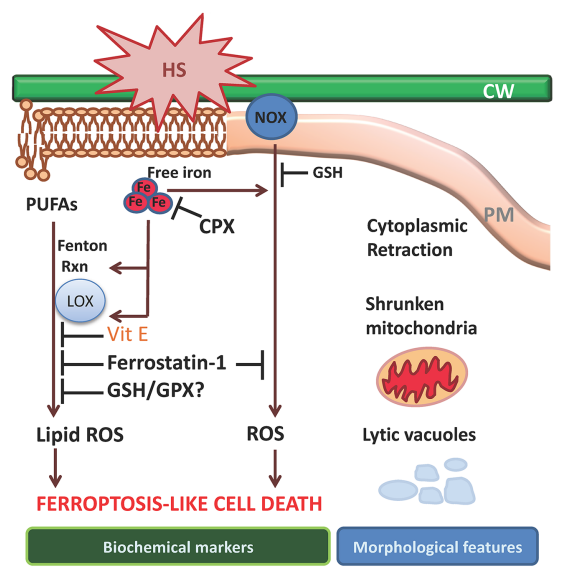

Figure 3. Current understanding of the molecular mechanisms leading to ferroptosis-like cell death in plants. Cell death triggered by heat shock (HS) can be prevented by the canonical ferroptosis inhibitors ciclopirox $(\mathrm{Cpx})$ or ferrostatin-1 and is characterized by glutathione depletion and accumulation of ROS and lipid hydroperoxides. Dying cells exhibit retracted cytoplasm and shrunken mitochondria by electron microscopy as well as the presence of lytic vacuoles, while no obvious changes are noticeable in the nucleus.

Arabidopsis roots with ferroptosis inhibitors, such inhibitors cannot prevent depletion of glutathione and ascorbic acid antioxidants after heat shock, suggesting that glutathione and ascorbic acid depletion are early events in the cell death that follows heat shock and not downstream consequences of lipid peroxidation. A similar scenario has been observed in mammalian cell ferroptosis. Depletion of glutathione might occur in plants as a consequence of an overwhelming accumulation of unfolded proteins in the endoplasmic reticulum after heat shock, along with inactivation of glutathione biosynthesis (Ozgur et al. 2014; Yang et al. 2016b). As a consequence of glutathione depletion, ascorbic acid cannot be recycled in affected cells, which also might explain the low levels of reduced ascorbic acid detected in Arabidopsis roots exposed to heat shock (Foyer and Noctor 2011; Distefano et al. 2017).

Heat-shock $\left(55^{\circ} \mathrm{C}\right)$-induced cell death in Arabidopsis requires peroxidation of PUFAs (Distefano et al. 2017), as has been observed in human cancer cells (Skouta et al. 2014). Pretreatment of cells with PUFAs containing the heavy hydrogen isotope deuterium at bis-allylic carbons (D-PUFAs) greatly inhibits PUFA oxidation and prevents ferroptotic cell death in both human cancer cells exposed to erastin or RSL3 and Arabidopsis root hairs exposed to a $55^{\circ} \mathrm{C}$ heat shock (Distefano et al. 2017). As noted above, oxidation of membrane PUFA phospholipids can be driven by nonenzymatic Fenton chemistry or LOX enzymes (Schneider et al. 2008; Yang et al. 2016a). LOX-mediated PUFA oxidation is required for cell death under glutathione depletion conditions in human cancer cells (Yang et al. 2016a).

LOX activity is associated with cell death in plant systems. The Arabidopsis genome encodes four lipoxgenases that are annotated as LOX1, LOX2, LOX3, and LOX5, while the proteins encoded by two additional loci are annotated as LOX family proteins and named LOX4 and LOX6 (Umate 2011). LOX activation has been frequently associated with cell death in Arabidopsis plants undergoing $\mathrm{HR}$ an senescence and in response to $\mathrm{H}_{2} \mathrm{O}_{2}$ (Maccarrone et al. 2001; Liu and Han 2010; Zoeller et al. 2012).

Blocking the activity of LOXs in lentil root protoplasts with monoclonal antibodies prevents root protoplast cell death induced by $\mathrm{H}_{2} \mathrm{O}_{2}$ (MacCarrone et al. 2000). Silencing of LOX genes attenuated programmed cell death associated with infection with Potato virus $X-Y$ (PVX-PVY) and Tomato spotted wilt virus (TSWV) in Nicotiana benthamiana (Garcia-Marcos et al. 2013), and LOX overexpression in Arabidopsis plants conferred enhanced HRinduced cell death (Hwang and Hwang 2010). Together, these reports suggest that ferroptotic cell death might be involved in other scenarios in plants besides heat-shockinduced cell death. In particular, HR-induced cell death appears to have many overlapping features with ferroptosis as it was defined in mammalian cells. For example, high-affinity iron uptake mechanisms such as siderophore-mediated iron acquisition are known to be essential for the virulence of fungi and bacteria (Greenshields et al. 2007; Dellagi et al. 2009). Thus, iron-sequestering mechanisms that prevent cell death in the host may have conferred a selective advantage on plant pathogens during evolution, as it would allow them to overcome a barrier for infection; namely, ferroptosis during HR.

The Arabidopsis genome encodes eight GPX enzymes (AtGPX1 to AtGPX8) that have different subcellular localizations, suggesting that GPX activities might respond specifically in particular cell compartments after stress. AtGPX8, which localizes to the cytosol and nucleus, plays a role in modulating cell survival in Arabidopsis roots exposed to paraquat and in plants under light stress (Gaber et al. 2012). In addition, expression of a tomato phospholipid-like GPX-encoding gene (LePHGPX) inhibits cell death induced by salt and heat stress in tobacco (Nicotiana tabacum) plants (Chen et al. 2004). Although more research is needed to assess the role of plant GPXs in cell death regulation, it is likely that glutathione depletion in plants inactivates GPXs, as occurs in mammalian cells, leading to an overwhelming accumulation of lipid peroxides and cell death.

In conclusion, a ferroptosis-like cell death process has been described in plants during heat shock, and other events appear to trigger a similar pathway in diverse plant species. In particular, HR-related cell death upon infection exhibits biochemical and morphological similarities to ferroptosis. Still, additional components of the plant pathways involved in ferroptosis remain to be identified. Even with many characteristics conserved between plant and animal cells, lipid peroxidation mechanisms, targets, and regulatory networks are still not established in plants and are key subjects of future studies.

\section{Bacteria, archaea, and fungi}

Enzymatic iron-dependent catalysis of the oxygenation of polyunsaturated phospholipids and regulation of this 
process by thiols under the control of nonheme peroxidases represent a core lipid metabolic pathway underlying physiologically important signaling by many lipid mediators (Ji et al. 2011; Maulucci et al. 2016). These same pathways have now been associated with ferroptotic cell death in animals and plants (Magtanong et al. 2016; Gaschler and Stockwell 2017). The parallels between these metabolic processes indicate that they may have common ancestry and raise the question of the driving selective pressure that sustained these death-inducing mechanisms throughout evolution. One approach to understand the ancient role of cell death driven by lipid peroxidation is to consider the role of ferroptotic cell death in evolutionarily distant species. However, we are not aware of studies on the biological role or occurrence of ferroptosis in bacteria or archaea, thus prompting us to perform an indirect analysis of the potential role of this cell death program in these distantly related organisms.

Iron and thiols are universal and necessary components of life (Toyokuni 2014; Berndt and Lillig 2017; Sanchez et al. 2017). While phospholipids are components of all cell membranes, polyunsaturation is not an absolute requirement in all species, and archaea, bacteria, and fungi frequently contain poorly oxidizable saturated or monounsaturated lipid molecules (Suutari and Laakso 1994; Siliakus et al. 2017). The fundamental differences in membrane lipids between archaeal, bacterial, and eukaryotic cells are probably the main reasons for the different susceptibilities of archaeal and bacterial strains versus eukaryotic cells to ferroptosis. The so-called "lipid divide" is based on the representation of "archaetidic acid" lipids in archaea versus "phosphatidic acid" lipids in bacteria and eukarya. Archaetidic acid (also known as di-O-geranylgeranyl-glyceryl phosphate) contains two saturated methyl-branched isoprenoids connected by ether bonds to the $s n-2$ and $s n-3$ position of glycerol-1 phosphate. In addition, tetraether (glycerol-dialkyl-glycerol-tetraether) lipids are characteristic of archaea. In contrast, phosphatidic acid is composed of two fatty acid hydrocarbon chains esterified to the sn- 1 and sn- 2 positions of glycerol-3 phosphate.

These specific features of core lipids are essential for membrane adaptation, permeability, and fluidity, realized via changes in lipid composition that enable a species to thrive in challenging biotopes. In archaea, this is achieved mainly through alterations of monounsaturated diethers, isoprenoid hydroxylation, and the tetraether:diether ratio. In bacteria, distinct targets of lipid-based adaptation include mainly variable contents of monounsaturated, short chain, and branched chain fatty acids (Suutari and Laakso 1994; Siliakus et al. 2017; Varnava et al. 2017). These saturated and monounsaturated lipids, common for many species of archaea in different habitats, including microbiomes in animals and humans, are not readily oxidized at moderate temperatures ("normal" for higher organisms), whereas lipids in thermophilic archaea organisms may get oxidized at "normal" (for them) temperatures up to $122^{\circ} \mathrm{C}$ (Takai et al. 2000; Quince et al. 2017). Thus, ferroptosis in thermophilic organisms may not require PUFAs.
Both nonenzymatic lipid peroxidation and enzymatic dioxygenase oxidation by LOXs have been considered as generators of proferroptotic signals (Shah et al. 2017; Tyurina et al. 2017b). While random free radical reactions are known to propagate dependent on the number of readily abstractable bis-allylic hydrogens in PUFA lipids (Gardner 1989) and generate myriad diversified products (Salomon 2012), tightly controlled enzymatic LOX-catalyzed reactions generate specific products (Newcomer and Brash 2015). Recent work identified hydroperoxy-arachidonoyl$\mathrm{PE}$ and hydroperoxy-adrenoyl-PE as the major proferroptotic lipid peroxidation signals (Doll et al. 2017; Kagan et al. 2017) formed by the LOX/PEBP1 complex (Wenzel et al. 2017). Notably, LOX-like sequences have been identified in bacteria, archaea, and eukarya (Horn et al. 2015). Close to 60 LOX-like sequences were discovered in studies of 13,000 bacterial genomes (Horn et al. 2015). However, the presence of catalytically active LOXs in archaea is still controversial due to the lack of functional data and the lack of oxidizable lipids (Ivanov et al. 2010).

The majority of bacterial membranes contains saturated or monounsaturated lipids (Strahl and Errington 2017). However, some free-living bacteria isolated from cold ocean depths, many of them members of the Shewanella genus, produce PUFAs, including eicosapentaenoic acid (EPA; 20:5n-3) and DHA (22:6n-3) (Dailey et al. 2015). These PUFA-based phospholipids are readily oxidizable and can represent substrates for the formation of proferroptotic signals. Moreover, even bacteria that normally do not synthesize PUFA lipids can acquire them from environmental sources and assimilate them into their membranes. For example, pathogenic Vibrio species (Vibrio cholerae, Vibrio parahaemolyticus, and Vibrio vulnificus) possess the machinery for the accumulation of PUFA and integration into membrane phospholipids (Moravec et al. 2017). Lipid unsaturation affects membrane permeability, motility, and biofilm formation and changes sensitivity to cell death by anti-microbial peptides. Such effects could presumably result in the triggering of ferroptosis in bacteria.

Some pathogenic bacteria express dioxygenases that are specialized for oxygenation of PUFA lipids in spite of the fact that these cells do not contain these oxidizable substrates. For example, strains of Pseudomonas aeruginosa express a LOX, pLoxA (Vance et al. 2004; Banthiya et al. 2016; Kalms et al. 2017), with substrate specificity and products very similar to that of mammalian 15-LOX, which is known to generate proferroptotic peroxy-adrenoyl-PE and peroxy-arachidonoyl-PE species. The bacterial enzyme can oxidize membrane phospholipids and cause the death of target mammalian cells (e.g., erythrocytes and A549 cells) (Aldrovandi et al. 2018). However, the ferroptotic nature of this death has not been confirmed.

Similarly, yeast cells, which normally do not synthesize PUFAs, can accumulate them from the environment and integrate them into membrane phospholipids (Tyurina et al. 2017a). Cell death has been documented in several CoQ-deficient Saccharomyces cerevisiae (coq) mutants and wild-type yeast cells supplemented with PUFA and subjected to oxidative stress (Hill et al. 2012). 
As described previously, reduction of ferroptotic hydroperoxy-arachidonoyl-PE and hydroperoxy-adrenoyl-PE in a glutathione-dependent reaction is a function of GPX4 (Ursini et al. 1982). A search for phospholipid hydroperoxide GPXs similar to GPX4 in archaea and bacteria did not reveal such an enzyme in these species. While bacteria do not appear to contain this enzyme, they do secrete factors that affect GPX4 expression and activity in mammalian (host) cells, as has been shown for Salmonella typhimurium (Agbor et al. 2014). SipA, an effector secreted from $S$. typhimurium, was shown to be responsible for a decrease in intestinal epithelial GPX4 levels and activity (Agbor et al. 2014). Notably S. typhimurium can cause non-caspase-dependent intestinal epithelial cell death (Schauser et al. 2005); the role of ferroptosis has not been explored yet in this context. In contrast, yeast cells do have hydroperoxy-phospholipid peroxidase activity (Avery and Avery 2001). For example, S. cerevisiae expresses three GPX4-like proteins, one of which (GPX3) readily reduces hydroperoxy-phospholipids (Avery et al. 2004). The potential association of this enzyme in yeast with ferroptosis can be deduced from the decreased abundance of phospholipids (and cytotoxicity) induced by cadmium and linoleic acid hydroperoxide in GPX3-deficient yeast cells (Muthukumar et al. 2011; O'Doherty et al. 2013).

Further detailed studies of ferroptosis pathway components and regulators may uncover a possible ancient origin and role of ferroptosis in archaea, bacteria, and fungi or their participation in nondeath mechanisms. These studies have to be performed carefully, as use of only a few characteristic ferroptosis inhibitors may yield misleading results, as illustrated by a study on macrophages infected with the pathogenic yeast Histoplasma capsulatum (Horwath et al. 2017). It was found that a prototypical ferroptosis inhibitor, ferrostatin-1, reduced the death of macrophages, implying a possible ferroptotic mechanism. However, more detailed studies revealed that this was not due to suppression of ferroptosis in target cells but was due to direct inhibitory effects of ferrostatin-1 on growth of $H$. capsulatum and the related species Paracoccidioides lutzii and Blastomyces dermatitidis, as other ferroptosis inhibitors (e.g., liproxstatin-1) did not exert this effect.

In summary, there is strong evidence for ferroptosis existing as a regulated cell death pathway in mammals (particularly mice) and plants. Similar regulators are found in other nonmammalian vertebrates, such as fish, reptiles, and birds, although the extent to which ferroptosis per se operates in these species is not clear. More distantly related eukaryotes, such as yeast, appear competent to undergo ferroptosis when supplemented with PUFAs, although they may not ordinarily use this process. Finally, prokaryotes and eukaryotes may in some cases subvert ferroptosis in mammalian hosts and might even themselves undergo ferroptosis in the relatively rare cases in which they incorporate environmental PUFAs into their membranes or when they operate at high temperatures. We suggest that the study of ferroptosis and lipid peroxidation in diverse species is a fertile ground for future investigations.

\section{Acknowledgments}

We thank the following funding organizations for support: the National Institutes of Health (R35CA209896 and P01CA087497 to B.R.S., and U19AI068021, NS076511, and NS061817 to V.E.K. and H.B.), Deutsche Forschungsgemeinschaft (CO 291/ 2-3 and CO 291/5-1 to M.C.), the German Federal Ministry of Education and Research (01EK1611B and 03VP04260 to M.C.), the Human Frontier Science Program (RGP0013 to M.C. and V.E.K.), and the Agencia Nacional de Promoción Científica y Tecnológica (Proyectos de Investigación Científica y Tecnológica [PICT] 2013-1372 and PICT 2016-0110 to G.C.P.).

\section{References}

Agbor TA, Demma Z, Mrsny RJ, Castillo A, Boll EJ, McCormick BA. 2014. The oxido-reductase enzyme glutathione peroxidase 4 (GPX4) governs Salmonella Typhimurium-induced neutrophil transepithelial migration. Cell Microbiol 16: 1339-1353.

Ahmad F, Liu X, Zhou Y, Yao H, Zhao F, Ling Z, Xu C. 2016. Assessment of thyroid endocrine system impairment and oxidative stress mediated by cobalt ferrite $\left(\mathrm{CoFe}_{2} \mathrm{O}_{4}\right)$ nanoparticles in zebrafish larvae. Environ Toxicol 31: 2068-2080.

Aldrovandi M, Banthiya S, Meckelmann S, Zhou Y, Heydeck D, O'Donnell VB, Kuhn H. 2018. Specific oxygenation of plasma membrane phospholipids by Pseudomonas aeruginosa lipoxygenase induces structural and functional alterations in mammalian cells. Biochim Biophys Acta 1863: 152-164.

Andrews RM, Thompson MB, Greene VW. 2013. Does low gas permeability of rigid-shelled gekkotan eggs affect embryonic development? I Exp Zool A Ecol Genet Physiol 319: 259-267.

Angeli JPF, Shah R, Pratt DA, Conrad M. 2017. Ferroptosis inhibition: mechanisms and opportunities. Trends Pharmacol Sci 38: 489-498.

Avery AM, Avery SV. 2001. Saccharomyces cerevisiae expresses three phospholipid hydroperoxide glutathione peroxidases. I Biol Chem 276: 33730-33735.

Avery AM, Willetts SA, Avery SV. 2004. Genetic dissection of the phospholipid hydroperoxidase activity of yeast gpx3 reveals its functional importance. J Biol Chem 279: 46652-46658.

Babin PJ, Vernier JM. 1989. Plasma lipoproteins in fish. J Lipid Res 30: 467-489.

Banthiya S, Kalms J, Galemou Yoga E, Ivanov I, Carpena X, Hamberg M, Kuhn H, Scheerer P. 2016. Structural and functional basis of phospholipid oxygenase activity of bacterial lipoxygenase from Pseudomonas aeruginosa. Biochim Biophys Acta 1861: 1681-1692.

Berndt C, Lillig CH. 2017. Glutathione, glutaredoxins, and iron. Antioxid Redox Signal 27: 1235-1251.

Bollhoner B, Prestele J, Tuominen H. 2012. Xylem cell death: emerging understanding of regulation and function. $I$ Exp Bot 63: 1081-1094.

Braga MM, Silva ES, Moraes TB, Schirmbeck GH, Rico EP, Pinto CB, Rosemberg DB, Dutra-Filho CS, Dias RD, Oliveira DL, et al. 2016. Brain zinc chelation by diethyldithiocarbamate increased the behavioral and mitochondrial damages in zebrafish subjected to hypoxia. Sci Rep 6: 20279.

Brigelius-Flohe R, Maiorino M. 2013. Glutathione peroxidases. Biochim Biophys Acta 1830: 3289-3303.

Brutsch SH, Wang CC, Li L, Stender H, Neziroglu N, Richter C, Kuhn H, Borchert A. 2015. Expression of inactive glutathione peroxidase 4 leads to embryonic lethality, and inactivation of 
the alox 15 gene does not rescue such knock-in mice. Antioxid Redox Signal 22: 281-293.

Burger J. 1994. Heavy metals in avian eggshells: another excretion method. J Toxicol Environ Health 41: 207-220.

Cambier S, Benard G, Mesmer-Dudons N, Gonzalez P, Rossignol R, Brethes D, Bourdineaud JP. 2009. At environmental doses, dietary methylmercury inhibits mitochondrial energy metabolism in skeletal muscles of the zebrafish (Danio rerio). Int J Biochem Cell Biol 41: 791-799.

Cambier S, Gonzalez P, Mesmer-Dudons N, Brethes D, Fujimura M, Bourdineaud JP. 2012. Effects of dietary methylmercury on the zebrafish brain: histological, mitochondrial, and gene transcription analyses. Biometals 25: 165-180.

Canli O, Alankus YB, Grootjans S, Vegi N, Hultner L, Hoppe PS, Schroeder T, Vandenabeele P, Bornkamm GW, Greten FR. 2016. Glutathione peroxidase 4 prevents necroptosis in mouse erythroid precursors. Blood 127: 139-148.

Cao C, Fan R, Zhao J, Zhao X, Yang J, Zhang Z, Xu S. 2017. Impact of exudative diathesis induced by selenium deficiency on lncRNAs and their roles in the oxidative reduction process in broiler chick veins. Oncotarget 8: 20695-20705.

Cardoso BR, Hare DJ, Bush AI, Roberts BR. 2017. Glutathione peroxidase 4: a new player in neurodegeneration? Mol Psychiatry 22: 328-335.

Carlson BA, Tobe R, Yefremova E, Tsuji PA, Hoffmann VJ, Schweizer U, Gladyshev VN, Hatfield DL, Conrad M. 2016. Glutathione peroxidase 4 and vitamin E cooperatively prevent hepatocellular degeneration. Redox Biol 9: 22-31.

Chaipayang S, Songsiriritthigul C, Chen CJ, Palacios PM, Pierce BS, Jangpromma N, Klaynongsruang S. 2017. Purification, characterization, cloning and structural analysis of Crocodylus siamensis ovotransferrin for insight into functions of iron binding and autocleavage. Comp Biochem Physiol B Biochem Mol Biol 212: 59-69.

Chen S, Vaghchhipawala Z, Li W, Asard H, Dickman MB. 2004. Tomato phospholipid hydroperoxide glutathione peroxidase inhibits cell death induced by Bax and oxidative stresses in yeast and plants. Plant Physiol 135: 1630-1641.

Chen L, Hambright WS, Na R, Ran Q. 2015. Ablation of ferroptosis inhibitor glutathione peroxidase 4 in neurons results in rapid motor neuron degeneration and paralysis. I Biol Chem 290: 28097-28106.

Choi CQ. 2013. The fate of the plant embryo's suspensor: balancing life and death. PLoS Biol 11: e1001656.

Choi J, Leonard SW, Kasper K, McDougall M, Stevens JF, Tanguay RL, Traber MG. 2015. Novel function of vitamin E in regulation of zebrafish (Danio rerio) brain lysophospholipids discovered using lipidomics. J Lipid Res 56: 1182-1190.

Chowdhury VS, Tomonaga S, Ikegami T, Erwan E, Ito K, Cockrem JF, Furuse M. 2014. Oxidative damage and brain concentrations of free amino acid in chicks exposed to high ambient temperature. Comp Biochem Physiol A Mol Integr Physiol 169: 70-76.

Conrad M, Sato H. 2012. The oxidative stress-inducible cystine/ glutamate antiporter, system $\mathrm{X}_{\mathrm{c}}{ }^{-}$: cystine supplier and beyond. Amino Acids 42: 231-246.

Conrad M, Moreno SG, Sinowatz F, Ursini F, Kolle S, Roveri A, Brielmeier M, Wurst W, Maiorino M, Bornkamm GW. 2005. The nuclear form of phospholipid hydroperoxide glutathione peroxidase is a protein thiol peroxidase contributing to sperm chromatin stability. Mol Cell Biol 25: 7637-7644.

Conrad M, Sandin A, Forster H, Seiler A, Frijhoff J, Dagnell M, Bornkamm GW, Radmark O, Hooft van Huijsduijnen R, Aspenstrom P, et al. 2010. 12/15-lipoxygenase-derived lipid peroxides control receptor tyrosine kinase signaling through oxidation of protein tyrosine phosphatases. Proc Natl Acad Sci 107: 15774-15779.

Conrad M, Angeli JP, Vandenabeele P, Stockwell BR. 2016. Regulated necrosis: disease relevance and therapeutic opportunities. Nat Rev Drug Discov 15: 348-366.

Cork SC. 2000. Iron storage diseases in birds. Avian Pathol 29: $7-12$.

Courtois-Moreau CL, Pesquet E, Sjodin A, Muniz L, Bollhoner B, Kaneda M, Samuels L, Jansson S, Tuominen H. 2009. A unique program for cell death in xylem fibers of Populus stem. Plant $J$ 58: $260-274$.

Cramer SL, Saha A, Liu J, Tadi S, Tiziani S, Yan W, Triplett K, Lamb C, Alters SE, Rowlinson S, et al. 2017. Systemic depletion of L-cyst(e)ine with cyst/e)inase increases reactive oxygen species and suppresses tumor growth. Nat Med 23: 120-127.

Dailey FE, McGraw JE, Jensen BJ, Bishop SS, Lokken JP, Dorff KJ, Ripley MP, Munro JB. 2015. The microbiota of freshwater fish and freshwater niches contain omega-3 fatty acid-producing Shewanella species. Appl Environ Microbiol 82: 218-231.

Dalto DB, Matte JJ. 2017. Pyridoxine (vitamin $\mathrm{B}_{6}$ ) and the glutathione peroxidase system; a link between one-carbon metabolism and antioxidation. Nutrients 9: E189.

Davalos A, Miguel M, Bartolome B, Lopez-Fandino R. 2004. Antioxidant activity of peptides derived from egg white proteins by enzymatic hydrolysis. J Food Prot 67: 1939-1944.

Deeming DC, Pike TW. 2013. Embryonic growth and antioxidant provision in avian eggs. Biol Lett 9: 20130757.

Dellagi A, Segond D, Rigault M, Fagard M, Simon C, Saindrenan P, Expert D. 2009. Microbial siderophores exert a subtle role in Arabidopsis during infection by manipulating the immune response and the iron status. Plant Physiol 150: 1687-1696.

Distefano AM, Martin MV, Cordoba JP, Bellido AM, D'Ippolito S, Colman SL, Soto D, Roldan JA, Bartoli CG, Zabaleta EJ, et al. 2017. Heat stress induces ferroptosis-like cell death in plants. J Cell Biol 216: 463-476.

Dixon SJ, Lemberg KM, Lamprecht MR, Skouta R, Zaitsev EM, Gleason CE, Patel DN, Bauer AJ, Cantley AM, Yang WS, et al. 2012. Ferroptosis: an iron-dependent form of nonapoptotic cell death. Cell 149: 1060-1072.

Dixon SJ, Patel DN, Welsch ME, Skouta R, Lee ED, Hayano M, Thomas AG, Gleason CE, Tatonetti N, Slusher BS, et al. 2014. Pharmacological inhibition of cystine-glutamate exchange induces endoplasmic reticulum stress and ferroptosis. eLife 3: $\mathrm{e} 02523$.

Dixon SJ, Winter GE, Musavi LS, Lee ED, Snijder B, Rebsamen M, Superti-Furga G, Stockwell BR. 2015. Human haploid cell genetics reveals roles for lipid metabolism genes in nonapoptotic cell death. ACS Chem Biol 10: 1604-1609.

Doll S, Proneth B, Tyurina YY, Panzilius E, Kobayashi S, Ingold I, Irmler M, Beckers J, Aichler M, Walch A, et al. 2017. ACSL4 dictates ferroptosis sensitivity by shaping cellular lipid composition. Nat Chem Biol 13: 91-98.

Doyle SM, Diamond M, McCabe PF. 2010. Chloroplast and reactive oxygen species involvement in apoptotic-like programmed cell death in Arabidopsis suspension cultures. J Exp Bot 61: 473-482.

Drew MC, He CJ, Morgan PW. 2000. Programmed cell death and aerenchyma formation in roots. Trends Plant Sci 5: 123-127.

Drews GN, Koltunow AM. 2011. The female gametophyte. Arabidopsis Book 9: $\mathrm{e} 0155$.

Duan Y, Zhang W, Li B, Wang Y, Li K, Sodmergen, Han C, Zhang Y, Li X. 2010. An endoplasmic reticulum response pathway mediates programmed cell death of root tip induced by water stress in Arabidopsis. New Phytol 186: 681-695. 
Dutta A, Sinha DK. 2017. Zebrafish lipid droplets regulate embryonic ATP homeostasis to power early development. Open Biol 7: 170063 .

Enyedi B, Jelcic M, Niethammer P. 2016. The cell nucleus serves as a mechanotransducer of tissue damage-induced inflammation. Cell 165: 1160-1170.

Ewen KM, Kleser M, Bernhardt R. 2011. Adrenodoxin: the archetype of vertebrate-type [2Fe-2S] cluster ferredoxins. Biochim Biophys Acta 1814: 111-125.

Foyer CH, Noctor G. 2011. Ascorbate and glutathione: the heart of the redox hub. Plant Physiol 155: 2-18.

Fradejas N, Carlson BA, Rijntjes E, Becker NP, Tobe R, Schweizer U. 2013. Mammalian Trit1 is a tRNA([Ser]Sec)-isopentenyl transferase required for full selenoprotein expression. Biochem J 450: 427-432.

Friedmann Angeli JP, Schneider M, Proneth B, Tyurina YY, Tyurin VA, Hammond VI, Herbach N, Aichler M, Walch A, Eggenhofer $\mathrm{E}$, et al. 2014. Inactivation of the ferroptosis regulator Gpx4 triggers acute renal failure in mice. Nat Cell Biol 16: $1180-1191$.

Furlong RA, Narain Y, Rankin J, Wyttenbach A, Rubinsztein DC. 2000. a-Synuclein overexpression promotes aggregation of mutant huntingtin. Biochem J 346(Pt 3): 577-581.

Gaber A, Ogata T, Maruta T, Yoshimura K, Tamoi M, Shigeoka S. 2012. The involvement of Arabidopsis glutathione peroxidase 8 in the suppression of oxidative damage in the nucleus and cytosol. Plant Cell Physiol 53: 1596-1606.

Galluzzi L, Vitale I, Aaronson SA, Abrams JM, Adam D, Agostinis P, Alnemri ES, Altucci L, Amelio I, Andrews DW, et al. 2018. Molecular mechanisms of cell death: recommendations of the Nomenclature Committee on Cell Death 2018. Cell Death Differ 25: 486-541.

Gao M, Monian P, Quadri N, Ramasamy R, Jiang X. 2015. Glutaminolysis and transferrin regulate ferroptosis. Mol Cell 59: 298-308.

Gao M, Monian P, Pan Q, Zhang W, Xiang J, Jiang X. 2016. Ferroptosis is an autophagic cell death process. Cell Res 26: 1021-1032.

Garcia-Marcos A, Pacheco R, Manzano A, Aguilar E, Tenllado F. 2013. Oxylipin biosynthesis genes positively regulate programmed cell death during compatible infections with the synergistic pair potato virus $\mathrm{X}$-potato virus $\mathrm{Y}$ and Tomato spotted wilt virus. J Virol 87: 5769-5783.

Gardner HW. 1989. Oxygen radical chemistry of polyunsaturated fatty acids. Free Radic Biol Med 7: 65-86.

Gaschler MM, Stockwell BR. 2017. Lipid peroxidation in cell death. Biochem Biophys Res Commun 482: 419-425.

Ge J, Li H, Sun F, Li X-N, Lin J, Xia J, Zhang C, Li J-L. 2017. Transport stress-induced cerebrum oxidative stress is not mitigated by activating the Nrf2 antioxidant defense response in newly hatched chicks1. I Anim Sci 95: 2871-2878.

Gellert G, Heinrichsdorff J. 2001. Effect of age on the susceptibility of zebrafish eggs to industrial wastewater. Water Res 35: 3754-3757.

Giraudeau M, Ducatez S. 2016. Co-adjustment of yolk antioxidants and androgens in birds. Biol Lett 12: 20160676.

Glisic B, Mihaljevic I, Popovic M, Zaja R, Loncar J, Fent K, Kovacevic R, Smital T. 2015. Characterization of glutathione-Stransferases in zebrafish (Danio rerio). Aquat Toxicol 158: 50-62.

Goto M, Shibazaki K. 1971. Effect of the oxidation of oils on the deterioration of foods part II. Effects of the food components on linoleic acid oxidation. Nippon Shokuhin Kogyo Gakkaishi 18: 277-283.
Greenshields DL, Liu G, Wei Y. 2007. Roles of iron in plant defence and fungal virulence. Plant Signal Behav 2: 300-302.

Griffin A, Parajes S, Weger M, Zaucker A, Taylor AE, O'Neil DM, Muller F, Krone N. 2016. Ferredoxin $1 \mathrm{~b}(\mathrm{Fdx} 1 \mathrm{~b})$ is the essential mitochondrial redox partner for cortisol biosynthesis in zebrafish. Endocrinology 157: 1122-1134.

Guérin P, El Mouatassim S, Ménézo Y. 2001. Oxidative stress and protection against reactive oxygen species in the pre-implantation embryo and its surroundings. Hum Reprod Update 7: 175-189.

Gunawardena AH, Greenwood JS, Dengler NG. 2004. Programmed cell death remodels lace plant leaf shape during development. Plant Cell 16: 60-73.

Gutierrez AM, Reboredo GR, Catala A. 2002. Fatty acid profiles and lipid peroxidation of microsomes and mitochondria from liver, heart and brain of Cairina moschata. Int J Biochem Cell Biol 34: 605-612.

Gutierrez AM, Reboredo GR, Mosca SM, Catala A. 2004. Fatty acid composition and lipid peroxidation induced by ascorbate-Fe ${ }^{2+}$ in different organs of goose (Anser anser). Comp Biochem Physiol C Toxicol Pharmacol 137: 123-132.

Hambright WS, Fonseca RS, Chen L, Na R, Ran Q. 2017. Ablation of ferroptosis regulator glutathione peroxidase 4 in forebrain neurons promotes cognitive impairment and neurodegeneration. Redox Biol 12: 8-17.

Hensley K, Kotake Y, Sang H, Pye QN, Wallis GL, Kolker LM, Tabatabaie T, Stewart CA, Konishi Y, Nakae D, et al. 2000. Dietary choline restriction causes complex I dysfunction and increased $\mathrm{H}_{2} \mathrm{O}_{2}$ generation in liver mitochondria. Carcinogenesis 21: 983-989.

Hill S, Lamberson CR, Xu L, To R, Tsui HS, Shmanai VV, Bekish AV, Awad AM, Marbois BN, Cantor CR, et al. 2012. Small amounts of isotope-reinforced polyunsaturated fatty acids suppress lipid autoxidation. Free Radic Biol Med 53: 893-906.

Hoekstra KA, Velleman SG. 2008. Brain microvascular and intracranial artery resistance to atherosclerosis is associated with heme oxygenase and ferritin in Japanese quail. Mol Cell Biochem 307: 1-12.

Holtta-Vuori M, Salo VT, Nyberg L, Brackmann C, Enejder A, Panula P, Ikonen E. 2010. Zebrafish: gaining popularity in lipid research. Biochem J 429: 235-242.

Horn T, Adel S, Schumann R, Sur S, Kakularam KR, Polamarasetty A, Redanna P, Kuhn H, Heydeck D. 2015. Evolutionary aspects of lipoxygenases and genetic diversity of human leukotriene signaling. Prog Lipid Res 57: 13-39.

Horwath MC, Bell-Horwath TR, Lescano V, Krishnan K, Merino EJ, Deepe GS Jr. 2017. Antifungal activity of the lipophilic antioxidant ferrostatin-1. Chembiochem 18: 2069-2078.

Hou W, Xie Y, Song X, Sun X, Lotze MT, Zeh HJ III, Kang R, Tang D. 2016. Autophagy promotes ferroptosis by degradation of ferritin. Autophagy 12: 1425-1428.

Hu L, Sun C, Luan J, Lu L, Zhang S. 2015. Zebrafish phosvitin is an antioxidant with non-cytotoxic activity. Acta Biochim Biophys Sin 47: 349-354.

Huh GH, Damsz B, Matsumoto TK, Reddy MP, Rus AM, Ibeas II, Narasimhan ML, Bressan RA, Hasegawa PM. 2002. Salt causes ion disequilibrium-induced programmed cell death in yeast and plants. Plant J 29: 649-659.

Hwang IS, Hwang BK. 2010. The pepper 9-lipoxygenase gene CaLOX1 functions in defense and cell death responses to microbial pathogens. Plant Physiol 152: 948-967.

Ibrahim HR, Hoq MI, Aoki T. 2007. Ovotransferrin possesses SOD-like superoxide anion scavenging activity that is promoted by copper and manganese binding. Int J Biol Macromol 41: 631-640. 
Imai H, Hirao F, Sakamoto T, Sekine K, Mizukura Y, Saito M, Kitamoto T, Hayasaka M, Hanaoka K, Nakagawa Y. 2003. Early embryonic lethality caused by targeted disruption of the mouse PHGPx gene. Biochem Biophys Res Commun 305: 278-286.

Ingold I, Aichler M, Yefremova E, Roveri A, Buday K, Doll S, Tasdemir A, Hoffard N, Wurst W, Walch A, et al. 2015. Expression of a catalytically inactive mutant form of glutathione peroxidase 4 (Gpx4) confers a dominant-negative effect in male fertility. J Biol Chem 290: 14668-14678.

Ingold I, Berndt C, Schmitt S, Doll S, Poschmann G, Buday K, Roveri A, Peng X, Porto Freitas F, Seibt T, et al. 2018. Selenium utilization by GPX4 is required to prevent hydroperoxide-induced ferroptosis. Cell 172: 409-422 e421.

Ishikawa S, Yano Y, Arihara K, Itoh M. 2004. Egg yolk phosvitin inhibits hydroxyl radical formation from the fenton reaction. Biosci Biotechnol Biochem 68: 1324-1331.

Ishimoto T, Nagano O, Yae T, Tamada M, Motohara T, Oshima H, Oshima M, Ikeda T, Asaba R, Yagi H, et al. 2011. CD44 variant regulates redox status in cancer cells by stabilizing the $\mathrm{xCT}$ subunit of system $\mathrm{X}_{\mathrm{c}}{ }^{-}$and thereby promotes tumor growth. Cancer Cell 19: 387-400.

Ito $F$, Nishiyama $T$, Shi L, Mori $M$, Hirayama $T$, Nagasawa $H$, Yasui H, Toyokuni S. 2016. Contrasting intra- and extracellular distribution of catalytic ferrous iron in ovalbumin-induced peritonitis. Biochem Biophys Res Commun 476: 600-606.

Ivanov I, Heydeck D, Hofheinz K, Roffeis J, O'Donnell VB, Kuhn H, Walther M. 2010. Molecular enzymology of lipoxygenases. Arch Biochem Biophys 503: 161-174.

Jenko K, Karouna-Renier NK, Hoffman DJ. 2012. Gene expression, glutathione status, and indicators of hepatic oxidative stress in laughing gull (Larus atricilla) hatchlings exposed to methylmercury. Environ Toxicol Chem 31: 2588-2596.

Ji RR, Xu ZZ, Strichartz G, Serhan CN. 2011. Emerging roles of resolvins in the resolution of inflammation and pain. Trends Neurosci 34: 599-609.

Jishage K, Tachibe T, Ito T, Shibata N, Suzuki S, Mori T, Hani T, Arai H, Suzuki H. 2005. Vitamin E is essential for mouse placentation but not for embryonic development itself. Biol Reprod 73: 983-987.

Jones AM. 2001. Programmed cell death in development and defense. Plant Physiol 125: 94-97.

Kagan VE, Mao G, Qu F, Angeli JP, Doll S, Croix CS, Dar HH, Liu B, Tyurin VA, Ritov VB, et al. 2017. Oxidized arachidonic and adrenic PEs navigate cells to ferroptosis. Nat Chem Biol 13: 81-90.

Kalms J, Banthiya S, Galemou Yoga E, Hamberg M, Holzhutter HG, Kuhn H, Scheerer P. 2017. The crystal structure of Pseudomonas aeruginosa lipoxygenase Ala420Gly mutant explains the improved oxygen affinity and the altered reaction specificity. Biochim Biophys Acta 1862: 463-473.

Kang B, Jiang D, Ma R, He H. 2015. Evidence for a role of ferritin heavy chain in mediating reproductive processes of geese. Reprod Biol 15: 205-209.

Kariya K, Demiral T, Sasaki T, Tsuchiya Y, Turkan I, Sano T, Hasezawa S, Yamamoto Y. 2013. A novel mechanism of aluminum-induced cell death involving vacuolar processing enzyme and vacuolar collapse in tobacco cell line BY-2. J Inorg Biochem 128: 196-201.

Kim SY, Noguera JC, Tato A, Velando A. 2013. Vitamins, stress and growth: the availability of antioxidants in early life influences the expression of cryptic genetic variation. I Evol Biol 26: 1341-1352.

Kirkwood JS, Lebold KM, Miranda CL, Wright CL, Miller GW, Tanguay RL, Barton CL, Traber MG, Stevens JF. 2012. Vita- min $\mathrm{C}$ deficiency activates the purine nucleotide cycle in zebrafish. J Biol Chem 287: 3833-3841.

Lachaier E, Louandre C, Godin C, Saidak Z, Baert M, Diouf M, Chauffert B, Galmiche A. 2014. Sorafenib induces ferroptosis in human cancer cell lines originating from different solid tumors. Anticancer Res 34: 6417-6422.

Lamonte G, Tang X, Chen JL, Wu J, Ding CK, Keenan MM, Sangokoya C, Kung HN, Ilkayeva O, Boros LG, et al. 2013. Acidosis induces reprogramming of cellular metabolism to mitigate oxidative stress. Cancer Metab 1: 23.

Lebold KM, Kirkwood JS, Taylor AW, Choi J, Barton CL, Miller GW, La Du J, Jump DB, Stevens JF, Tanguay RL, et al. 2013. Novel liquid chromatography-mass spectrometry method shows that vitamin E deficiency depletes arachidonic and docosahexaenoic acids in zebrafish (Danio rerio) embryos. Redox Biol 2: 105-113.

Leist M, Raab B, Maurer S, Rosick U, Brigelius-Flohe R. 1996. Conventional cell culture media do not adequately supply cells with antioxidants and thus facilitate peroxide-induced genotoxicity. Free Radic Biol Med 21: 297-306.

Li Q, Han X, Lan X, Gao Y, Wan J, Durham F, Cheng T, Yang J, Wang Z, Jiang C, et al. 2017. Inhibition of neuronal ferroptosis protects hemorrhagic brain. JCI Insight 2: e90777.

Lin YF, Tsai HL, Lee YC, Chang SJ. 2005. Maternal vitamin E supplementation affects the antioxidant capability and oxidative status of hatching chicks. J Nutr 135: 2457-2461.

Ling SC, Polymenidou M, Cleveland DW. 2013. Converging mechanisms in ALS and FTD: disrupted RNA and protein homeostasis. Neuron 79: 416-438.

Linkermann A, Skouta R, Himmerkus N, Mulay SR, Dewitz C, De Zen F, Prokai A, Zuchtriegel G, Krombach F, Welz PS, et al. 2014. Synchronized renal tubular cell death involves ferroptosis. Proc Natl Acad Sci 111: 16836-16841.

Liu S, Han B. 2010. Differential expression pattern of an acidic 9/13-lipoxygenase in flower opening and senescence and in leaf response to phloem feeders in the tea plant. BMC Plant Biol 10: 228.

Liu Y, Xiong Y, Bassham DC. 2009. Autophagy is required for tolerance of drought and salt stress in plants. Autophagy 5: 954-963.

Liu H, Takano T, Peatman E, Abernathy J, Wang S, Sha Z, Kucuktas H, Xu DH, Klesius P, Liu Z. 2010. Molecular characterization and gene expression of the channel catfish ferritin $\mathrm{H}$ subunit after bacterial infection and iron treatment. $J$ Exp Zool A Ecol Genet Physiol 313: 359-368.

Liu J, Chen Z, He J, Zhang Y, Zhang T, Jiang Y. 2014. Anti-oxidative and anti-apoptosis effects of egg white peptide, Trp-AsnTrp-Ala-Asp, against $\mathrm{H}_{2} \mathrm{O}_{2}$-induced oxidative stress in human embryonic kidney 293 cells. Food Funct 5: 3179-3188.

Lorincz T, Jemnitz K, Kardon T, Mandl J, Szarka A. 2015. Ferroptosis is involved in acetaminophen induced cell death. Pathol Oncol Res 21: 1115-1121.

Louandre C, Ezzoukhry Z, Godin C, Barbare JC, Maziere JC, Chauffert B, Galmiche A. 2013. Iron-dependent cell death of hepatocellular carcinoma cells exposed to sorafenib. Int J Cancer 133: 1732-1742.

Lu CL, Baker RC. 1986. Characteristics of egg yolk phosvitin as an antioxidant for inhibiting metal-catalyzed phospholipid oxidations. Poult Sci 65: 2065-2070.

MacCarrone M, Van Zadelhoff G, Veldink GA, Vliegenthart JF, Finazzi-Agro A. 2000. Early activation of lipoxygenase in lentil (Lens culinaris) root protoplasts by oxidative stress induces programmed cell death. Eur J Biochem 267: 5078-5084. 
MacCarrone M, Melino G, Finazzi-Agro A. 2001. Lipoxygenases and their involvement in programmed cell death. Cell Death Differ 8: 776-784.

MacLeod AK, McMahon M, Plummer SM, Higgins LG, Penning TM, Igarashi K, Hayes JD. 2009. Characterization of the cancer chemopreventive NRF2-dependent gene battery in human keratinocytes: demonstration that the KEAP1-NRF2 pathway, and not the BACH1-NRF2 pathway, controls cytoprotection against electrophiles as well as redox-cycling compounds. Carcinogenesis 30: 1571-1580.

Magtanong L, Ko PJ, Dixon SJ. 2016. Emerging roles for lipids in non-apoptotic cell death. Cell Death Differ 23: 1099-1109.

Maiorino M, Conrad M, Ursini F. 2017. GPx4, lipid peroxidation, and cell death: discoveries, rediscoveries, and open issues. Antioxid Redox Signal doi: 10.1089/ars.2017.7115.

Maldonado EN. 2017. VDAC-tubulin, an anti-Warburg pro-oxidant switch. Front Oncol 7: 4.

Mancias JD, Wang X, Gygi SP, Harper JW, Kimmelman AC. 2014. Quantitative proteomics identifies NCOA4 as the cargo receptor mediating ferritinophagy. Nature 509: 105-109.

Marty F. 1999. Plant vacuoles. Plant Cell 11: 587-600.

Matsushita M, Freigang S, Schneider C, Conrad M, Bornkamm GW, Kopf M. 2015. T cell lipid peroxidation induces ferroptosis and prevents immunity to infection. J Exp Med 212: 555568.

Maulucci G, Daniel B, Cohen O, Avrahami Y, Sasson S. 2016. Hormetic and regulatory effects of lipid peroxidation mediators in pancreatic $\beta$ cells. Mol Aspects Med 49: 49-77.

McDougall MQ, Choi J, Stevens JF, Truong L, Tanguay RL, Traber MG. 2016. Lipidomics and $\mathrm{H}_{2}^{18} \mathrm{O}$ labeling techniques reveal increased remodeling of DHA-containing membrane phospholipids associated with abnormal locomotor responses in $\alpha$-tocopherol deficient zebrafish (Danio rerio) embryos. Redox Biol 8: 165-174.

McDougall M, Choi J, Truong L, Tanguay R, Traber MG. 2017. Vitamin E deficiency during embryogenesis in zebrafish causes lasting metabolic and cognitive impairments despite refeeding adequate diets. Free Radic Biol Med 110: 250-260.

Mendieta-Serrano MA, Schnabel D, Lomeli H, Salas-Vidal E. 2015. Spatial and temporal expression of zebrafish glutathione peroxidase $4 \mathrm{a}$ and $\mathrm{b}$ genes during early embryo development. Gene Expr Patterns 19: 98-107.

Miller GW, Ulatowski L, Labut EM, Lebold KM, Manor D, Atkinson J, Barton CL, Tanguay RL, Traber MG. 2012. The a-tocopherol transfer protein is essential for vertebrate embryogenesis. PLOS ONE 7: e47402.

Monge CC, Ostojic H, Aguilar R, Cifuentes V. 2000. Reduced oxygen diffusion across the shell of Gray gull (Larus modestus) eggs. Biol Res 33: 209-214.

Monroig O, Rotllant J, Sanchez E, Cerda-Reverter JM, Tocher DR. 2009. Expression of long-chain polyunsaturated fatty acid (LCPUFA) biosynthesis genes during zebrafish Danio rerio early embryogenesis. Biochim Biophys Acta 1791: 1093-1101.

Montillet JL, Chamnongpol S, Rusterucci C, Dat J, van de Cotte B, Agnel JP, Battesti C, Inze D, Van Breusegem F, Triantaphylides C. 2005. Fatty acid hydroperoxides and $\mathrm{H}_{2} \mathrm{O}_{2}$ in the execution of hypersensitive cell death in tobacco leaves. Plant Physiol 138: 1516-1526.

Moravec AR, Siv AW, Hobby CR, Lindsay EN, Norbash LV, Shults DJ, Symes SJK, Giles DK. 2017. Exogenous polyunsaturated fatty acids impact membrane remodeling and affect virulence phenotypes among pathogenic Vibrio species. Appl Environ Microbiol 83: e01415-17.
Mullen PJ, Yu R, Longo J, Archer MC, Penn LZ. 2016. The interplay between cell signalling and the mevalonate pathway in cancer. Nat Rev Cancer 16: 718-731.

Muthukumar K, Rajakumar S, Sarkar MN, Nachiappan V. 2011. Glutathione peroxidase3 of Saccharomyces cerevisiae protects phospholipids during cadmium-induced oxidative stress. Antonie Van Leeuwenhoek 99: 761-771.

Newcomer ME, Brash AR. 2015. The structural basis for specificity in lipoxygenase catalysis. Protein Sci 24: 298-309.

Nimalaratne C, Wu J. 2015. Hen egg as an antioxidant food commodity: a review. Nutrients 7: 8274-8293.

Noctor G, Mhamdi A, Chaouch S, Han Y, Neukermans J, Marquez-Garcia B, Queval G, Foyer CH. 2012. Glutathione in plants: an integrated overview. Plant Cell Environ 35: 454-484.

O'Doherty PJ, Lyons V, Higgins VJ, Rogers PJ, Bailey TD, Wu MJ. 2013. Transcriptomic insights into the molecular response of Saccharomyces cerevisiae to linoleic acid hydroperoxide. Free Radic Res 47: 1054-1065.

Oladipo GO, Ibukun EO. 2017. BioActivities of Coturnix japonica (quail) egg yolk and albumen against physiological stress. Food Sci Nutr 5: 334-343.

Osellame LD, Blacker TS, Duchen MR. 2012. Cellular and molecular mechanisms of mitochondrial function. Best Pract Res Clin Endocrinol Metab 26: 711-723.

Ozgur R, Turkan I, Uzilday B, Sekmen AH. 2014. Endoplasmic reticulum stress triggers ROS signalling, changes the redox state, and regulates the antioxidant defence of Arabidopsis thaliana. J Exp Bot 65: 1377-1390.

Parolini M, Khoriauli L, Possenti CD, Colombo G, Caprioli M, Santagostino M, Nergadze SG, Milzani A, Giulotto E, Saino N. 2017. Yolk vitamin E prevents oxidative damage in gull hatchlings. R Soc Open Sci 4: 170098.

Pavet V, Olmos E, Kiddle G, Mowla S, Kumar S, Antoniw J, Alvarez ME, Foyer CH. 2005. Ascorbic acid deficiency activates cell death and disease resistance responses in Arabidopsis. Plant Physiol 139: 1291-1303.

Pavone S, Salamida S, Pecorelli I, Rossi E, Manuali E. 2014. Deadly outbreak of iron storage disease (ISD) in Italian birds of the family Turdidae. J Vet Med Sci 76: 1209-1212.

Pelka KE, Henn K, Keck A, Sapel B, Braunbeck T. 2017. Size does matter-determination of the critical molecular size for the uptake of chemicals across the chorion of zebrafish (Danio rerio) embryos. Aquat Toxicol 185: 1-10.

Peng X, Cui H, Fang J, Zuo Z, Deng J, Pan K, Lai W, Zhou Y. 2012. Low selenium diet alters cell cycle phase, apoptotic population and modifies oxidative stress markers of spleens in broilers. Biol Trace Elem Res 148: 182-186.

Qualhato G, Rocha TL, de Oliveira Lima EC, e Silva DM, Cardoso JR, Koppe Grisolia C, de Sabóia-Morais SMT. 2017. Genotoxic and mutagenic assessment of iron oxide (maghemite- $\gamma-\mathrm{Fe}_{2} \mathrm{O}_{3}$ ) nanoparticle in the guppy Poecilia reticulata. Chemosphere 183: 305-314.

Quince C, Walker AW, Simpson JT, Loman NJ, Segata N. 2017. Shotgun metagenomics, from sampling to analysis. Nat Biotechnol 35: 833-844.

Ren C, Hu X, Li X, Zhou Q. 2016. Ultra-trace graphene oxide in a water environment triggers Parkinson's disease-like symptoms and metabolic disturbance in zebrafish larvae. Biomaterials 93: 83-94.

Reyes-Becerril M, Angulo-Valadez C, Macias ME, Angulo M, Ascencio-Valle F. 2014. Iron bioavailability in larvae yellow snapper (Lutjanus argentiventris): cloning and expression analysis of ferritin-H. Fish Shellfish Immunol 37: 248-255. 
Rui BR, Shibuya FY, Kawaoku AJT, Losano JDA, Angrimani DSR, Dalmazzo A, Nichi M, Pereira RJG. 2017. Impact of induced levels of specific free radicals and malondialdehyde on chicken semen quality and fertility. Theriogenology 90: 11-19.

Salomon RG. 2012. Structural identification and cardiovascular activities of oxidized phospholipids. Circ Res 111: 930-946.

Sanchez M, Sabio L, Galvez N, Capdevila M, Dominguez-Vera JM. 2017. Iron chemistry at the service of life. IUBMB Life 69: 382-388.

Santambrogio P, Biasiotto G, Sanvito F, Olivieri S, Arosio P, Levi S. 2007. Mitochondrial ferritin expression in adult mouse tissues. J Histochem Cytochem 55: 1129-1137.

Sato H, Shiiya A, Kimata M, Maebara K, Tamba M, Sakakura Y, Makino N, Sugiyama F, Yagami K, Moriguchi T, et al. 2005. Redox imbalance in cystine/glutamate transporter-deficient mice. J Biol Chem 280: 37423-37429.

Schafer FQ, Buettner GR. 2000. Acidic pH amplifies iron-mediated lipid peroxidation in cells. Free Radic Biol Med 28: 1175-1181.

Schauser K, Olsen JE, Larsson LI. 2005. Salmonella typhimurium infection in the porcine intestine: evidence for caspase-3-dependent and -independent programmed cell death. Histochem Cell Biol 123: 43-50.

Schneider C, Porter NA, Brash AR. 2008. Routes to 4-hydroxynonenal: fundamental issues in the mechanisms of lipid peroxidation. J Biol Chem 283: 15539-15543.

Schneider M, Forster H, Boersma A, Seiler A, Wehnes H, Sinowatz F, Neumuller C, Deutsch MJ, Walch A, Hrabe de Angelis $M$, et al. 2009. Mitochondrial glutathione peroxidase 4 disruption causes male infertility. FASEB J 23: 3233-3242.

Schoenmakers E, Agostini M, Mitchell C, Schoenmakers N, Papp L, Rajanayagam O, Padidela R, Ceron-Gutierrez L, Doffinger $\mathrm{R}$, Prevosto C, et al. 2010. Mutations in the selenocysteine insertion sequence-binding protein 2 gene lead to a multisystem selenoprotein deficiency disorder in humans. I Clin Invest 120: 4220-4235.

Schriever SC, Zimprich A, Pfuhlmann K, Baumann P, Giesert F, Klaus V, Kabra DG, Hafen U, Romanov A, Tschop MH, et al. 2017. Alterations in neuronal control of body weight and anxiety behavior by glutathione peroxidase 4 deficiency. Neuroscience 357: 241-254.

Seiler A, Schneider M, Forster H, Roth S, Wirth EK, Culmsee C, Plesnila N, Kremmer E, Radmark O, Wurst W, et al. 2008. Glutathione peroxidase 4 senses and translates oxidative stress into 12/15-lipoxygenase dependent- and AIF-mediated cell death. Cell Metab 8: 237-248.

Senda K, Ogawa K. 2004. Induction of PR-1 accumulation accompanied by runaway cell death in the lsd 1 mutant of Arabidopsis is dependent on glutathione levels but independent of the redox state of glutathione. Plant Cell Physiol 45: 1578-1585.

Seymour RS, Wagner-Amos K. 2008. Non-invasive measurement of oxygen partial pressure, lateral diffusion and chorioallantoic blood flow under the avian eggshell. Comp Biochem Physiol A Mol Integr Physiol 150: 258-264.

Shah R, Margison K, Pratt DA. 2017. The potency of diarylamine radical-trapping antioxidants as inhibitors of ferroptosis underscores the role of autoxidation in the mechanism of cell death. ACS Chem Biol 12: 2538-2545.

Shah R, Shchepinov MS, Pratt DA. 2018. Resolving the role of lipoxygenases in the initiation and execution of ferroptosis. ACS Cent Sci 4: 387-396.

Shimada K, Hayano M, Pagano NC, Stockwell BR. 2016a. Cellline selectivity improves the predictive power of pharmacogenomic analyses and helps identify NADPH as biomarker for ferroptosis sensitivity. Cell Chem Biol 23: 225-235.
Shimada K, Skouta R, Kaplan A, Yang WS, Hayano M, Dixon SJ, Brown LM, Valenzuela CA, Wolpaw AJ, Stockwell BR. 2016b. Global survey of cell death mechanisms reveals metabolic regulation of ferroptosis. Nat Chem Biol 12: 497-503.

Siliakus MF, van der Oost J, Kengen SWM. 2017. Adaptations of archaeal and bacterial membranes to variations in temperature, $\mathrm{pH}$ and pressure. Extremophiles 21: 651-670.

Skouta R, Dixon SJ, Wang J, Dunn DE, Orman M, Shimada K, Rosenberg P, Lo D, Weinberg J, Linkermann A, et al. 2014. Ferrostatins inhibit oxidative lipid damage and cell death in diverse disease models. I Am Chem Soc 136: 4551-4556.

Skrivan M, Skrivanova V, Marounek M. 2005. Effects of dietary zinc, iron, and copper in layer feed on distribution of these elements in eggs, liver, excreta, soil, and herbage. Poult Sci 84: 1570-1575.

Smith AC, Mears AJ, Bunker R, Ahmed A, MacKenzie M, Schwartzentruber JA, Beaulieu CL, Ferretti E, Consortium FC, Majewski J, et al. 2014. Mutations in the enzyme glutathione peroxidase 4 cause Sedaghatian-type spondylometaphyseal dysplasia. J Med Genet 51: 470-474.

Stockwell BR, Friedmann Angeli JP, Bayir H, Bush AI, Conrad M, Dixon SJ, Fulda S, Gascon S, Hatzios SK, Kagan VE, et al. 2017. Ferroptosis: a regulated cell death nexus linking metabolism, redox biology, and disease. Cell 171: 273-285.

Strahl H, Errington J. 2017. Bacterial membranes: structure, domains, and function. Annu Rev Microbiol 71: 519-538.

Sun Y, Hayakawa S, Chuamanochan M, Fujimoto M, Innun A, Izumori K. 2006. Antioxidant effects of Maillard reaction products obtained from ovalbumin and different D-aldohexoses. Biosci Biotechnol Biochem 70: 598-605.

Surai PF. 2000. Effect of selenium and vitamin E content of the maternal diet on the antioxidant system of the yolk and the developing chick. Br Poult Sci 41: 235-243.

Surai PF, Noble RC, Speake BK. 1999. Relationship between vitamin E content and susceptibility to lipid peroxidation in tissues of the newly hatched chick. Br Poult Sci 40: 406-410.

Suutari M, Laakso S. 1994. Microbial fatty acids and thermal adaptation. Crit Rev Microbiol 20: 285-328.

Takai K, Sugai A, Itoh T, Horikoshi K. 2000. Palaeococcus ferrophilus gen. nov., sp. nov., a barophilic, hyperthermophilic archaeon from a deep-sea hydrothermal vent chimney. Int $J$ Syst Evol Microbiol 50: 489-500.

Tapiero H, Townsend DM, Tew KD. 2003. The antioxidant role of selenium and seleno-compounds. Biomed Pharmacother 57: 134-144.

Taylor MR, Hurley JB, Van Epps HA, Brockerhoff SE. 2004. A zebrafish model for pyruvate dehydrogenase deficiency: rescue of neurological dysfunction and embryonic lethality using a ketogenic diet. Proc Natl Acad Sci 101: 4584-4589.

Toyokuni S. 2014. Iron and thiols as two major players in carcinogenesis: friends or foes? Front Pharmacol 5: 200.

Tuo Q-Z, Lei P, Jackman KA, Li X-I, Xiong H, Li X-L, Liuyang Z-Y, Roisman L, Zhang S-T, Ayton S, et al. 2017. Tau-mediated iron export prevents ferroptotic damage after ischemic stroke. Mol Psychiatry 22: 1520-1530.

Tyurina YY, Lou W, Qu F, Tyurin VA, Mohammadyani D, Liu J, Huttemann M, Frasso MA, Wipf P, Bayir H, et al. 2017a. Lipidomics characterization of biosynthetic and remodeling pathways of cardiolipins in genetically and nutritionally manipulated yeast cells. ACS Chem Biol 12: 265-281.

Tyurina YY, Shrivastava I, Tyurin VA, Mao G, Dar HH, Watkins S, Epperly M, Bahar I, Shvedova AA, Pitt B, et al. 2017b. 'Only a life lived for others is worth living': redox signaling by oxygenated phospholipids in cell fate decisions. Antioxid Redox Signal doi: 10.1089/ars.2017.7124. 
Ueta T, Inoue T, Furukawa T, Tamaki Y, Nakagawa Y, Imai H, Yanagi Y. 2012. Glutathione peroxidase 4 is required for maturation of photoreceptor cells. J Biol Chem 287: 7675-7682.

Umate P. 2011. Genome-wide analysis of lipoxygenase gene family in Arabidopsis and rice. Plant Signal Behav 6: 335-338.

Ursini F, Maiorino M, Valente M, Ferri L, Gregolin C. 1982. Purification from pig liver of a protein which protects liposomes and biomembranes from peroxidative degradation and exhibits glutathione peroxidase activity on phosphatidylcholine hydroperoxides. Biochim Biophys Acta 710: 197-211.

Van Breusegem F, Dat JF. 2006. Reactive oxygen species in plant cell death. Plant Physiol 141: 384-390.

Vance RE, Hong S, Gronert K, Serhan CN, Mekalanos JJ. 2004. The opportunistic pathogen Pseudomonas aeruginosa carries a secretable arachidonate 15-lipoxygenase. Proc Nat1 Acad Sci 101: 2135-2139.

van Doorn WG, Beers EP, Dangl JL, Franklin-Tong VE, Gallois P, Hara-Nishimura I, Jones AM, Kawai-Yamada M, Lam E, Mundy J, et al. 2011. Morphological classification of plant cell deaths. Cell Death Differ 18: 1241-1246.

Varnava KG, Ronimus RS, Sarojini V. 2017. A review on comparative mechanistic studies of antimicrobial peptides against archaea. Biotechnol Bioeng 114: 2457-2473.

Viswanathan VS, Ryan MJ, Dhruv HD, Gill S, Eichhoff OM, Seashore-Ludlow B, Kaffenberger SD, Eaton JK, Shimada K, Aguirre AJ, et al. 2017. Dependency of a therapy-resistant state of cancer cells on a lipid peroxidase pathway. Nature 547: 453-457.

Wagner-Amos K, Seymour RS. 2002. Effect of regional changes to shell conductance on oxygen consumption and growth of chicken embryos. Respir Physiol 129: 385-395.

Wang YQ, Chang SY, Wu Q, Gou YJ, Jia L, Cui YM, Yu P, Shi ZH, $\mathrm{Wu}$ WS, Gao G, et al. 2016. The protective role of mitochondrial ferritin on erastin-induced ferroptosis. Front Aging Neurosci 8: 308.

Wenzel SE, Tyurina YY, Zhao J, St. Croix CM, Dar HH, Mao G, Tyurin VA, Anthonymuthu TS, Kapralov AA, Amoscato AA, et al. 2017. PEBP1 wardens ferroptosis by enabling lipoxygenase generation of lipid death signals. Cell 171: 628-641. e26.

Wirth EK, Conrad M, Winterer J, Wozny C, Carlson BA, Roth S, Schmitz D, Bornkamm GW, Coppola V, Tessarollo L, et al. 2010. Neuronal selenoprotein expression is required for interneuron development and prevents seizures and neurodegeneration. FASEB T 24: 844-852.

Wirth EK, Bharathi BS, Hatfield D, Conrad M, Brielmeier M, Schweizer U. 2014. Cerebellar hypoplasia in mice lacking selenoprotein biosynthesis in neurons. Biol Trace Elem Res 158: $203-210$.

Wortmann M, Schneider M, Pircher J, Hellfritsch J, Aichler M, Vegi N, Kolle P, Kuhlencordt P, Walch A, Pohl U, et al. 2013. Combined deficiency in glutathione peroxidase 4 and vitamin E causes multiorgan thrombus formation and early death in mice. Circ Res 113: 408-417.

Wu SM, Liu JH, Shu LH, Chen CH. 2015. Anti-oxidative responses of zebrafish (Danio rerio) gill, liver and brain tissues upon acute cold shock. Comp Biochem Physiol A Mol Integr Physiol 187: 202-213.

Wu SM, Shu LH, Liu JH. 2016. Anti-oxidative functions of $\mathrm{mt} 2$ and smtB mRNA expression in the gills and brain of zebrafish (Danio rerio) upon cadmium exposure. Fish Physiol Biochem 42: $1709-1720$.

Xie Z, Klionsky DJ. 2007. Autophagosome formation: core machinery and adaptations. Nat Cell Biol 9: 1102-1109.
Xie HT, Wan ZY, Li S, Zhang Y. 2014. Spatiotemporal production of reactive oxygen species by NADPH oxidase is critical for tapetal programmed cell death and pollen development in Arabidopsis. Plant Cell 26: 2007-2023.

Xu M, Shangguan X, Wang W, Chen J. 2007. Antioxidative activity of hen egg ovalbumin hydrolysates. Asia Pac J Clin Nutr 16: $178-182$.

Xu S-W, Yao H-D, Zhang J, Zhang Z-W, Wang J-T, Zhang J-L, Jiang Z-H. 2013. The oxidative damage and disbalance of calcium homeostasis in brain of chicken induced by selenium deficiency. Biol Trace Elem Res 151: 225-233.

Yang WS, Stockwell BR. 2008. Synthetic lethal screening identifies compounds activating iron-dependent, nonapoptotic cell death in oncogenic-RAS-harboring cancer cells. Chem Biol 15: 234-245.

Yang KT, Lin CY, Huang HL, Liou JS, Chien CY, Wu CP, Huang $\mathrm{CW}, \mathrm{Ou} \mathrm{BR}$, Chen CF, Lee YP, et al. 2008. Expressed transcripts associated with high rates of egg production in chicken ovarian follicles. Mol Cell Probes 22: 47-54.

Yang WS, Sriramaratnam R, Welsch ME, Shimada K, Skouta R, Viswanathan VS, Cheah JH, Clemons PA, Shamji AF, Clish $\mathrm{CB}$, et al. 2014. Regulation of ferroptotic cancer cell death by Gpx4. Cell 156: 317-331.

Yang WS, Kim KJ, Gaschler MM, Patel M, Shchepinov MS, Stockwell BR. 2016a. Peroxidation of polyunsaturated fatty acids by lipoxygenases drives ferroptosis. Proc Natl Acad Sci 113: E4966-E4975.

Yang X, Srivastava R, Howell SH, Bassham DC. 2016b. Activation of autophagy by unfolded proteins during endoplasmic reticulum stress. Plant J 85: 83-95.

Yant LJ, Ran Q, Rao L, Van Remmen H, Shibatani T, Belter JG, Motta L, Richardson A, Prolla TA. 2003. The selenoprotein GPX4 is essential for mouse development and protects from radiation and oxidative damage insults. Free Radic Biol Med 34: 496-502.

Yao H, Zhao W, Zhao X, Fan R, Khoso PA, Zhang Z, Liu W, Xu S. 2014. Selenium deficiency mainly influences the gene expressions of antioxidative selenoproteins in chicken muscles. Biol Trace Elem Res 161: 318-327.

Yao H, Zhao X, Fan R, Sattar H, Zhao J, Zhao W, Zhang Z, Li Y, Xu S. 2017. Selenium deficiency-induced alterations in ion profiles in chicken muscle. PLoS One 12: 0184186.

Yuan H, Li X, Zhang X, Kang R, Tang D. 2016. Identification of ACSL4 as a biomarker and contributor of ferroptosis. Biochem Biophys Res Commun 478: 1338-1343.

Zeisel SH. 2013. Metabolic crosstalk between choline/1-carbon metabolism and energy homeostasis. Clin Chem Lab Med 51: 467-475.

Zeisel S. 2017. Choline, other methyl-donors and epigenetics. Nutrients 9: E445.

Zhang YZ, Ouyang YC, Hou Y, Schatten H, Chen DY, Sun QY. 2008. Mitochondrial behavior during oogenesis in zebrafish: a confocal microscopy analysis. Dev Growth Differ 50: 189-201.

Zhang QF, Li YW, Liu ZH, Chen QL. 2016. Reproductive toxicity of inorganic mercury exposure in adult zebrafish: histological damage, oxidative stress, and alterations of sex hormone and gene expression in the hypothalamic-pituitary-gonadal axis. Aquat Toxicol 177: 417-424.

Zoeller M, Stingl N, Krischke M, Fekete A, Waller F, Berger S, Mueller MJ. 2012. Lipid profiling of the Arabidopsis hypersensitive response reveals specific lipid peroxidation and fragmentation processes: biogenesis of pimelic and azelaic acid. Plant Physiol 160: 365-378. 


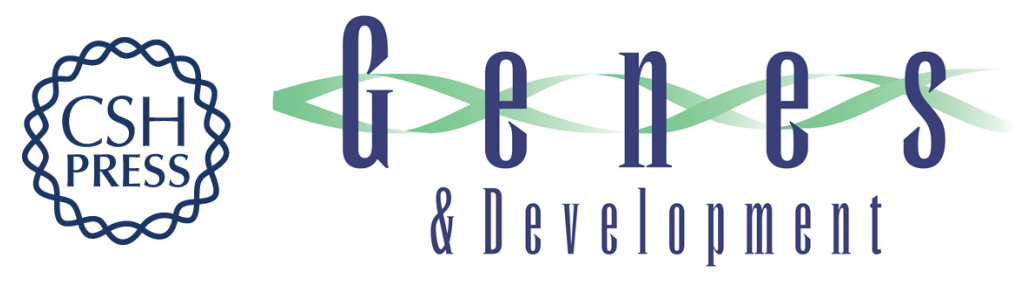

\title{
Regulation of lipid peroxidation and ferroptosis in diverse species
}

\author{
Marcus Conrad, Valerian E. Kagan, Hülya Bayir, et al.
}

Genes Dev. 2018, 32:

Access the most recent version at doi:10.1101/gad.314674.118

References This article cites 222 articles, 39 of which can be accessed free at: http://genesdev.cshlp.org/content/32/9-10/602.full.html\#ref-list-1

Creative This article is distributed exclusively by Cold Spring Harbor Laboratory Press for the first Commons License six months after the full-issue publication date (see http://genesdev.cshlp.org/site/misc/terms.xhtml). After six months, it is available under a Creative Commons License (Attribution-NonCommercial 4.0 International), as described at http://creativecommons.org/licenses/by-nc/4.0/.

Email Alerting Receive free email alerts when new articles cite this article - sign up in the box at the top Service right corner of the article or click here.

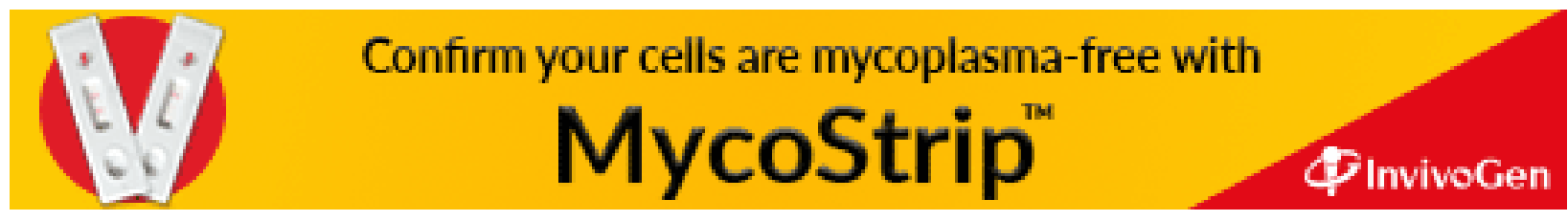

